\title{
THE CONCEPT OF ABUSE IN TAX MATTERS WITHIN EUROPEAN UNION LAW
}

\section{EL CONCEPTO DE ABUSO EN EL ÁMBITO TRIBUTARIO EN EL DERECHO DE LA UNIÓN EUROPEA}

\author{
DANiel E. MÁrquez LASSO \\ Profesor de Derecho Financiero y Tributario \\ Universidad de Santiago de Compostela \\ Abogado - Socio Director Stellvest tax legal advisory
}

Recibido: 03.05.2021 / Aceptado: 10.05.2021

DOI: https://doi.org/10.20318/cdt.2021.6263

\begin{abstract}
The principle of prohibition of abuse of rights is applicable in fields as varied as the free movement of goods (judgment of 10 of January 1985, Association des Centres distributeurs Leclerc and Thouars Distribution, Case 229/83), freedom to provide services (judgment of 3 of February 1993, Veronica Omroep Organisatie, Case C-148/91), public service contracts (judgment of 11 of December 2014, Azienda sanitaria locale n. 5 Spezzino and Others, Case C-113/13), freedom of establishment (judgment of 9 of March 1999, Centros, Case C-212/97), company law (judgment of 23 of March 2000, Diamantis, Case C-373/97), social security (judgments of 2 of May 1996, Paletta, Case C-206/94; of 6 of February 2018, Altun and Others, Case C-359/16; and of 11 of July 2018, Commission v Belgium, Case C-356/15), transport (judgment of 6 of April 2006, Agip Petroli, Case C-456/04), social policy (judgment of 28 of July 2016, Kratzer, Case C-423/15), restrictive measures (judgment of 21 of December 2011, Afrasiabi and Others, Case C-72/11) and value added tax (judgment of 21 of February 2006, Halifax and Others, Case C-255/02) and, in that sense, the EU principle of prohibition of abuse of law has been developing within the jurisprudence of the Court of Justice of the European Union since the mid-1970s, addressing it in multiple ways, not only in the face of different factual assumptions, which would be understandable and even necessary but, in its evolution, treating asymmetrically the handling of the requirements that must be met to reach the conclusion of the existence of practices abusive.
\end{abstract}

Keywords: Abuse of law, European Union Law, Jurisprudence, Tax Law.

Resumen: El principio de prohibición del abuso de derechos es aplicable en ámbitos tan variados como la libre circulación de mercancías (sentencia de 10 de enero de 1985, Association des Centres distributeurs Leclerc and Thouars Distribution, Asunto 229/83), libre prestación de servicios (sentencia de 3 de febrero de 1993, Veronica Omroep Organisatie, Asunto C-148/91), contratos públicos (sentencia de 11 de diciembre de 2014, Azienda sanitaria locale n. 5 Spezzino y otros, Asunto C-113/13), libertad de establecimiento (sentencia de 9 de marzo de 1999, Centros, Asunto C-212/97), derecho societario (sentencia de 23 de marzo de 2000, Diamantis, Asunto C-373/97), seguridad social (sentencias de 2 de mayo de 1996, Paletta, Asunto C-206/94; de 6 de febrero de 2018, Altun y otros, Asunto C-359/16; o de 11 de julio de 2018, Comisión/Bélgica, Asunto C-356/15), transporte (sentencia de 6 de abril de 2006, Agip Petroli, Asunto C-456/04), política social (sentencia de 28 de julio de 2016, Kratzer, Asunto C-423/15), medidas restrictivas (sentencia de 21 de diciembre de 2011, Afrasiabi y otros, Asunto C-72/11) o sobre el Impuesto sobre el Valor Añadido (sentencia de 21 de febrero de 2006, Halifax y otros, Asunto C-255/02) y, en este sentido, el principio de la Unión de prohibición del abuso de Estado se ha ido desarrollando dentro de la jurisprudencia del Tribunal de Justicia de la Unión Europea desde mediados de 
la década de 1970, abordándolo de múltiples maneras, no solo frente a diferentes supuestos de hecho, lo cual sería entendible y hasta necesario sino, en su evolución, tratando de manera asimétrica el manejo de los requisitos que han de concurrir para llegar a la conclusión de la existencia de prácticas abusivas.

Palabras clave: Abuso del derecho, Unión Europea, Jurisprudencia, Derecho fiscal y financiero.

Sumario: I. Introduction. II. The concept of abuse of law in the jurisprudence of the Court of the European Union: the prohibition of abuse in the European legal order. 1. Economic globalization and tax competition: tax planning and the general framework of the anti-abuse case. 2. Terminological and conceptual evolution of abuse of rights in the jurisprudence of the Court of Justice in the European Union: the abuse of freedoms of the European Union. A) The abuse of law within the European Union. B) The abuse of law in its application of EU Freedoms. 3. Synthesis of the evolution of the jurisprudence of the Court of Justice in the European Union. III. The jurisprudential doctrine on the abuse of rights on tax matters. 1. UE measures against abusive practices regarding tax. 2 . The fight against abusive practices such as justification of tax discriminatory or restriction of freedom of establishment rules. A) Factual situations that invoke the fight against abusive practices in taxation as justification. B) The jurisprudential doctrine of justification. a) The jurisprudential analysis of national anti-abuse tax law. b) Proportionality test and the existence of wholly artificial arrangements. IV. A concept of an abuse in UE law in tax matters.

\section{Introduction}

1. In this decade EU Member States face new challenges and have a strategic and fundamental objective to obtain an adequate level of revenue to finance public spending.

2. The economic globalization (corporate and private) puts pressure on the competitiveness of the tax systems, and within this framework the Member States have total freedom to establish their fiscal policy according to their needs and national objectives. Nevertheless, in the context of fiscal sovereignty integrated in a supranational framework, like the European Union, it is necessary to ensure that nonharmonized national tax systems work properly when interacting with each other, not only to overcome obstacles that could appear in the confrontation of national sovereignty facing European law, but also to avoid erosion of the tax bases of the Member States. It is becoming increasingly clear that the lack of coordination between the direct tax systems may lead to an erosion of tax revenues, undermining the ability of EU Member States to acquire balanced and efficient tax systems, which in turn, can affect the sustainability of the finance of social models in communal countries ${ }^{1}$.

3. Undoubtedly, a fiscal treatment in Europe, which purports to be coordinated and coherent, involves eliminating all traces of discrimination and double taxation (examples of challenges that make full coexistence difficult between Member State's own tax sovereigns and Laws within the European Union) as well as, obviously, reducing the costs of compliance of the legislation that involves the subject of more than one tax system.

4. However, discontinuities between tax systems due to the lack of targeted coordination can also lead to the existence of cases of unintentional non-taxation or, what could be more serious, to the existence of scope for abuse - both scenarios being equally detrimental to the interests of the Internal Market as these undermine the fairness and balance of the EU Member States' tax systems ${ }^{2}$. Combat-

\footnotetext{
${ }^{1}$ Communication from the Commission to the European Parliament, the Council, the European Economic and Social Committee and the Committee of the regions, European values in the globalised world Contribution of the Commission to the October meeting of Heads of State and Governmen, COM (2005) 525 final, Brussels, 3.11.2005.

${ }^{2}$ Communication from the Commission to the European Parliament, the Council, the European Economic and Social Committee, Co-ordinating Member States' direct tax systems in the Internal Market, COM (2006) 823, Brussels, 19.12.2006.
} 
ting abusive practices, balanced with the need of avoiding a disproportionate restriction in cross-border activity inside the European Union, are a challenge that not only does it the Member States, but also the Court itself, in its attempt to set a definition, as accurate as possible, for the term «abuse of rights».

5. This presents serious difficulties due to various factors: firstly, to abstract a unique concept of Legal abuse in different national legislations of Member States, because on the one hand, there is a diversity of rules, techniques, and concepts with anti-elusive outcomes, both in comparative Law and in the same national legislation. On the other hand, the fact that the reactions of the systems themselves are different depending on the variety of anti-abuse rules containing its legislation. This makes forming a homogeneous doctrine on legal abuse and consistently applying European Union law in its relationship with national law on this matter particularly complex. This leads to admit that secondly, there is not a generally valid definition of the concept at UE level. This doctrine is still in construction, as a consequence of a «process of dialogue between the Court of Justice in the European Union and national courts $\rangle^{3}$ or, like DE LA FERIA said, it is argued elsewhere that the process is better designated as a one of reverberation ${ }^{4}$. Finally, the difficulty that surrounds the complexity of the relationship between anti-abuse measures in national legal systems, and their compatibility with the European Union legal systems, especially with the practice of fundamental rights contained in the treaty that are a cornerstone in the construction of the European Union.

6. Yet despite the obvious difficulties, the purpose of this paper is none other than the study of anti-abuse doctrines that made the European Court of Justice. Though having great interest in the configuration of the doctrine at national levels, especially the Spanish doctrine, we understand that it is not appropriate to refer to them at this moment, given the limited research that is exclusive to a European Union level. Similarly, bearing in mind that the doctrine of Legal abuse originates in different areas related to fundamental freedoms, our main analysis objective focuses on the practice of freedom enactments. This is because in the practice of this freedom, where they have dictated the most complex declarations of the Court and where they have configured the important concept of a «wholly artificial arrangement» through notorious cases such as Cadbury, Schweppes, or Marks \& Spencer. Therefore, this study will focus on the identification, classification and analysis of the jurisprudence delivered by the Court, not only understanding the pioneering judgments in the construction of the doctrine, but also those that have been outlined, clarified, or expanded in the concept or its range of application, and contextualized in the factual circumstances in which the doctrine deals with abuse. In this research, we will try to extract a definition of abuse of law that may be useful to understand, in its innermost structure, what meaning reaches the teleological interpretation of rules and to what extent it influences the behaviour of subjects who are bound to them. The research is not simple, because the Court has had multiple ways of tackling the topic of legal abuse, and not only facing different factual circumstances, which would be understandable and even necessary, but in its evolution, it has treated management requirements asymmetrically that have to be met to reach the conclusion of the existence of abusive practices. Regarding the structure of the work, the start of the investigation will focus on, firstly, the terminological and conceptual study of the generic notion of abuse of law in the jurisprudence of the European Court of Justice, intending to cover the impact of the European Union freedom practices in order to try to conclude with a synthesis of the evolution of this doctrine.

7. The objective deals with the practice of the freedom of establishment and the impact that such exercise has on purely tax contexts, to then conduct a study of EU measures against abusive practices on fiscal matters, which will allow us to analyse the reaction mechanisms that the legal system has created against the practices mentioned and in cases which have been constitutive of justifications for discrimi-

\footnotetext{
${ }^{3}$ A. ZALASINSKI, "Some basic aspects of the concept of abuse in the tax case law of the European Court of Justice", in $\underline{I n-}$ tertax, vol. 36, n 4, 2008, p.157.

${ }^{4}$ R. DE LA Feria, "Introducing the Principle of Prohibition of Abuse of Law", in R. DE LA Feria and S. VogenaUer (Eds.), Prohibition of Abuse of Law: ¿A new general Principle of EU Law?, Oxford Hart Publishing, Oxford, 2011.
} 
natory treatment, or particularly restrictive of the freedom of establishment. To do this, understanding the factual assumptions which are invoked in the fight against abusive practices in taxation, its jurisprudential treatment, and most importantly, to get to know exactly when we are faced with the existence of a wholly artificial arrangement will allow us to develop, and justify, a concept of abuse of law within the European Union, despite the Court had been alluding to abuse and abusive practices in its rulings for more than forty years and, for a long time, however, the significance of these references was unclear ${ }^{5}$.

\section{The concept of abuse of law in the jurisprudence of the Court of the European Union: the pro- hibition of abuse in the European legal order}

\section{Economic globalization and tax competition: tax planning and the general framework of the anti-abuse case}

8. It is known that the implementation of general and specific anti-avoidance rules in an international environment is complex due to the diversity of legal rules and contexts that must be interpreted strictly ${ }^{6}$. In addition, all reflections on international tax law must involve the study of their integration into the current economic climate, and in this sense, we must have an obligatory reference to globalization or better said, all those sets of social relations that cause different phenomena of globalization?

9. It is evident that by the end of the $20^{\text {th }}$ century the economic situation had changed. On the one hand, we are witnessing the phenomenon of the internationalization of the economy as something totally inherent in the normal state of economic operators and, on the other hand, in dominating the idea of a free trade environment, that is fundamental to achieve an increase in economic welfare, national limitations of proceedings have disappeared or have been mitigated to expand market size. Thus, we are helping the well-known process of economic globalization, which we can say is represented by three main concepts; the liberalization of trades in goods markets, the liberalization of capital markets and a revolution in communications and computer technology (ICT), and consists of the progressive integration of the national economy into the international economy, so that its evolution depends increasingly on foreign markets and less on internal national politics, with an extremely high mobility of production factors (especially capital) that culminates in an ever-increasing supranational economic integration.

10. As a result of this economic integration, a growth in the coordination of fiscal politics in multijurisdictional structures has been observed, as well as the establishment of supranational bodies that protect these policies, it is posed a dilemma in the field of taxation: to what extent is this fact limiting the fiscal sovereignty of countries?

11. The analysis of the framework of work of states, in the fiscal sphere, entails that each one of those is sovereign to demand and adjust taxes levied on the income of its residents. This can be brought down to not only taxation of income obtained in the territory of State, but also to even those that can earn from foreign territories.

12. On one hand, the globalization and the absence of the International Tax Authority requires an increased coordination and mutual support between the national tax administrations. And on the other hand, the tax itself, which remains a matter of national sovereignty and implements the competitive po-

\footnotetext{
${ }^{5}$ R. DE la Feria, "EU General Anti-(Tax) Avoidance Mechanisms: From GAAP to GAAR" in G. Loutzenhiser and R. DE LA Feria (Eds.), The Dynamics of Taxation, Oxford Hart Publishing, Oxford, 2020.

${ }^{6}$ V. Ruiz Almendral, "El Fraude a la ley tributaria a examen (Los problemas de la aplicación práctica de la norma general anti-fraude del artículo 15 de la LGT a los ámbitos nacional y comunitario)", Thomson-Aranzadi, Pamplona, 2006, p. 143.

${ }^{7}$ B. De Sousa Santos, "Por una concepción multicultural de los derechos humanos", Universidad Nacional Autónoma de México, 1998, pp. 10-11.
} 
sition of States, which entails the constant search of preferential tax regimes to attract investment into its territory or in tax terms, non-resident tax bases.

13. Thus, in the context of rapid growth and mobility, the legislations sometimes remain obsolete or suffer significant gaps in the proliferation of situations for which they were not intended; the generation of new ways of business and the lack of uniformity between the laws within countries can lead to a paradox of which the same acts can be illegal in one country but totally legal in another, so each state can establish their policies to influence in the mobile tax bases ${ }^{8}$, in other words, in those incomes or capitals which can relocate themselves offering the best conditions for foreign investment in a race to the bottom phenomenon.

14. It is globalization and the spectacular development of communications that promote and help find the new ways of evading taxes ${ }^{9}$ which taxpayers are searching for by forcing tax legal instruments. In the case of the European Union, it is precisely a field where common situations live within a federal space (we refer to the UE freedoms of movement of capital and workers, freedom of establishment and freedom to provide services) with other more typical relations between fully independent States that have also worsened since 2004 by the addition of new countries. This situation has strengthened the fiscal competition between States that in the process, presents two distinguished aspects, on one hand, it speaks of healthy tax competition (referred to as this by the international doctrine) understood as the process of elimination of inefficiencies and the increase in the neutrality in the fiscal systems, executed with the intention to prevent the idea that taxation is an obstacle in the development of economic activities ${ }^{10}$.

15. The harmful fiscal tax competition appears in direct confrontation with the previous figure when the fiscal element is used to attract capital or tax bases. This has caused States to create non-corporate establishments with their own tax mechanisms, competing to attract investment projects with a high element of competition in terms of tax awards (tax holidays, favourable regulations, etc. ${ }^{11}$

16. Given the premise that we have seen that each state is sovereign to design their tax regime and establish their level of tax according to their public finance needs. Harmful tax competition appears when unjustified or exorbitant tax advantages appear, that end up being the foundation or at least one of the essential foundations in the location of an activity or income ${ }^{12}$.

17. Consequently, tax is going to be put between influencing factors at the time of making economic-finance decisions by operators, whose natural consequence is contemplating international tax planning as an economic strategy that tries to choose or construct a more efficient route to more efficient tax-action, in other words, that which is among all legal viable alternatives, allows to minimize the tax burden as a part of an economic planning and management of subjects. This on a purely competitive level, can become difficult for States to determine the taxable income of taxpayers given the leeway they have ${ }^{13}$, product of the high volume of financial resources likely to being mobilised

${ }^{8}$ J.M. CANTOS, "Consideraciones sobre la competencia fiscal en Europa", in AA.VV. XVII Encuentro de Economía Pública, 2010.

${ }^{9}$ F. Serrano Antón, "Las medidas antiabuso en los convenios para evitar la doble imposición internacional", in Serrano/ SOLER (Dirs.), Las medidas anti-abuso en la normativa interna española y en los convenios para evitar la doble imposición internacional y su compatibilidad con el Derecho Comunitario, Instituto de Estudios Fiscales, Madrid, 2002, p. 79.

${ }^{10}$ J.M. Vallejo Chamorro, "La competencia fiscal perniciosa en el seno de la OCDE y la Unión Europea", in Nuevas tendencias en economía y fiscalidad internacional, $\mathrm{n}^{\circ} 825$, p. 148.

${ }^{11}$ E. WiLDAsIn DaVID, "Fiscal Competition", IFIR Working Papers, 2005-05, June 2005, p. 1: the term fiscal competition may evoke images of one state pitted in a contest with another for a high-stakes manufacturing project, with politicians serving up juicy packages of tax holidays, infrastructure projects, regulatory relief, and direct subsidies to entice a firm and advance the cause of economic development, jobs, or other supposedly desirable economic outcomes.

${ }^{12}$ J.M. Vallejo Chamorro, "La competencia fiscal perniciosa en el seno de la OCDE y la Unión Europea”, cit., p. 148.

${ }^{13}$ Pollock and Shoup, "The Effect of Shifting the Property Tax Base from Improvement Value to Land Value: An Empirical Estimate", in Land Economics, vol. 53, n 1, 1977. 
and, also, the diversity of quantitative and qualitative offers that are fiscally attractive to preferential regimes. In this sense, the planning moves in a double border: on one hand, it will be understood as an economy of options fully lawful and legitimate ${ }^{14}$ conduct and, secondly, since there will be states establishing defence mechanisms that seek to prevent tax erosion derived from tax arbitrage, they will be configured as a synonym of circumvention whose defining element lies in being formally secundum legem, but in substance contrary to law; that is, they are illegal to go against the intent of the law without being illegitimate in its own meaning. However, exploitation of the differences between tax regimes and the consequent tax optimization is not necessarily unlawful, so that even its place in fraud schemes in tax law is easy to defend ${ }^{15}$.

18. The European Court of Justice has stated, in this respect that the concepts of tax evasion, fiscal fraud and abuse of tax legislation differ between Member States. In the United Kingdom, the concept of tax avoidance is legal, unlike tax evasion, which is illegal. The lack of a general concept of abuse in tax legislation in the UK makes it impossible to establish a common distinction in other Member States between abusive tax planning which is illegal, and simple fiscal planning, that despite being particularly unpopular for tax administration, is lega $1^{16}$.

19. So, if the question is what should be legitimate tax planning according to the laws in the European Union, it seems clear that the answer to this question should be that all fiscal planning is legitimate as long as it is not abusive but, to be able to defend this hypothesis, it is first essential to establish a detailed criterion to determine when an abuse of rights occurs ${ }^{17}$. In other words, when we could be facing an antisocial exercise of individual rights that has inspired us for no other motive other than reducing tax burdens.

20. It is undeniable that we are in an extremely globalised economic situation, where States compete to offer more and better competitive tax options and where the taxpayer has in his favour a variety of options that allows him to have more detailed planning. In the framework of the European Union, they have declared a series of UE freedoms that have had one purpose, which is simply the achievement of the Internal Market and although covered by said liberties, the citizens of the Member States can develop their economic interests they cannot deny the legitimate interest that a Member State may have in preventing some of its nationals, by means of facilities created under the Treaty, improperly circumventing their national legislation ${ }^{18}$.

21. Therefore, understanding the concept of abuse of rights is fundamental to understand the true extent of the imposed limitations in international fiscal planning and the exercise of the freedoms within the European Union involved, because by not doing so, unless a Europe free of boarders coordinates with the harmonisation of taxes on goods and capital, there will be a reorganization of production on comparative tax advantage rather than on comparative cost advantage ${ }^{19}$.

${ }^{14}$ A. Mondini, "Planificación Fiscal y Jurisprudencia del Tribunal de Justicia de la Comunidad Europea", Universidad de Bolonia, p. 2.

${ }^{15}$ V. Ruiz Almendral, “¿Tiene futuro el test de los motivos económicos válidos en las normas antiabuso? (sobre la planificación fiscal y las normas anti-abuso en el derecho de la Unión Europea)", in Revista de Contabilidad y Tributación CEF, $\mathrm{n}^{\circ}$ 329-330, p. 8.

${ }^{16}$ Judgment of 12 july 1988, Direct Cosmetics Ltd and Laughtons Photographs Ltd v Commissioners of Customs and Excise (Joined Cases 138/86 and 139/86) ECLI:EU:C:1988:383, par. 21-24.

${ }^{17}$ Opinion of Mr Advocate General Poiares Maduro delivered on 7 april 2005, Halifax, Case C-255/02.

${ }^{18}$ Judgment of 7 february 1979, Knoors, (Case 115/78) ECLI:EU:C:1979:31, para. 25.

${ }^{19}$ S. SinN, "The taming of Leviathan: competition among government", U.S. Congress, Joint Economic Committee (Ed.), Federal expenditure policy for economic growth and stability, Washington D.C., 1992, pp. 213-219. 


\section{Terminological and conceptual evolution of abuse of rights in the jurisprudence of the Court of Justice in the European Union: the abuse of freedoms of the European Union}

\section{A) The abuse of law within the European Union}

22. The concept of abuse of law is not novel at European level, and since the sentencing of Van Binsbergen ${ }^{20}$, the Court of Justice of the European Union, without using specifically the term abuse, established the first notes of its jurisprudential construction.

23. This construction, as we have already expressed, has been a process of dialogue between their own Court, and the Member States, carried out fundamentally through the national courts through preliminary rulings, which resulted in them being raised during the course of respective lawsuits.

24. It can therefore be said that the concept of abuse is a product of the search for solutions in the tension between the interests of the Union and national interests in the tribunal field, between the EU's single market and the tax interests of the States ${ }^{21}$.

25. However, it has not been a peaceful dialogue: during the process of constructing the concept, a multitude of terms have been used by the Court as if they were interchangeable, synonyms or including on certain occasions, elements which are indistinct or lacking their own independent meaning. In this regard, in their relative jurisprudence to this question they have used such varied terms such as, avoidance $^{22}$, fraud ${ }^{23}$, evasion ${ }^{24}$ or, in a more generally, they have used the term abusive practices ${ }^{25}$ reaching to assimilate the concept of fraudulent practices ${ }^{26}$.

26. NOGUEIRA claims that abuse, evasion, avoidance, fraud, abusive planning, illegitimate planning (...) are just some of the terms used to describe those human behaviours which, being carriers of a pathological element, are an affront to the normal operation of the tax system ${ }^{27}$. In addition, the Court is asymmetrical in its treatment of the anti-abuse doctrine, depending on the regulatory context, or fundamental freedoms faced with the rules contained in the Directives that are at stake, showing different levels of power when judging the analysed conduct ${ }^{28}$. In the already summoned Sentence of Van Binsbergen, the Court is going to establish a starting point to be kept constant in all its pronouncements and is none other than the fact that stakeholders cannot take advantage of Law within the European Union in an abusive or fraudulent way ${ }^{29}$. This revealed postulate seems obvious, and it is that they cannot deny the legitimate interest that a Member State may have in preventing that, taking advantage of the facilities created by the Treaty, some of their nationals try to abusively avoid the appliance of their national rules $^{30}$, making them unable to gain advantage through abuse or fraudulent conduct ${ }^{31}$. This comes

\footnotetext{
${ }^{20}$ Judgment of 3 december 1974, Van Binsbergen (Case C-33/74) ECLI:EU:C:1974:131.

${ }^{21}$ R. SANZ Gómez, "Las cláusulas anti-abuso específicas tributarias frente a las libertades de circulación de la Unión Europea”, Bosch Fiscalidad, 2010, p. 63.

${ }^{22}$ Van Binsbergen, cit.

${ }^{23}$ Direct Cosmetic and Laughtons Photographs Ltd, cit.

${ }^{24}$ Judgment of 17 july 1997, Leur-Blomen (Case C-28/95) ECLI:EU:C:1997:369.

${ }^{25}$ Judgment of 12 march 1996, Pafitis (Case C-441/93) ECLI:EU:C:1996:92.

${ }^{26}$ Judgment of 2 may 1996, Paletta (Case C-206/94) ECLI:EU:C:1996:182, para. 13.

${ }^{27}$ J.F.P. NogueIra, “Abuso de direito em fiscalidade directa”, in Revista da Faculdade de Direito da Universidade do Porto, 2010, p. 234.

${ }^{28}$ Vid V. Ruiz Almendral: “¿Tiene futuro el test de los motivos económicos válidos en las normas antiabuso?” cit., and R. SAnz Gómez, "Las cláusulas anti-abuso específicas tributarias frente a las libertades de circulación de la Unión Europea", cit.

${ }^{29}$ Vid. Van Binsbergen, cit., para. 13, Judgment of 5 october 1994, TV10 (Case C-23/93) ECLI:EU:C:1994:362, para. 21, Judgment of 10 january 1985, Leclerc (Case 229/83) ECLI:EU:C:1985:1, para. 27 and Judgment of 21 june 1988, Lair (Case 39/86) ECLI:EU:C:1988:322, para. 43.

${ }^{30}$ Knoors, cit., para. 25.

${ }^{31}$ Palletta, cit., para. 24.
} 
from reflecting on the main context in which the Court of Justice has analysed the concept of abuse and that is simply to abusively invoke the provisions of European Law, with the aim to obtain advantages in a way that disobeys the purposes and objectives of these dispositions. In other words, you cannot deny an EU Member State the right to adopt provisions to prevent the freedoms guaranteed by the treaty being used for a lender whose activity is entirely or mainly orientated towards their territory, in order to avoid the rules that would be applicable if they were established in the territory of that state.

27. However, the use of the UE freedoms to obtain a given application of a favourable legal regime (including tax) is not to be understood by the Court as abusive, instead finding it perfectly legitimate under UE law. This has been stated convincingly when it states that the simple exercise of the UE freedoms within the EU, in the search for beneficial legal regimes, cannot be invoked to justify a general presumption of abusive practises and serve as justification of measures that go against the practise of a fundamental freedom guaranteed by the EU Treaty ${ }^{32}$.

28. Therefore, we can state that under the Court, the EU freedoms have become genuine individual rights of economic agents operating in the common market, applicable before the states where these want to carry out an economic activity or investment in their state of residence ${ }^{33}$.

29. In this regard, the EU freedoms make up an essential point of reference to determine the objective and spirit of anti-abuse rules established by the EU Member States, it is necessary to understand clearly and concisely that the fundamental objective is constructing an internal market, therefore the integration of legal systems in the EU Member States have a requirement to eliminate or at least diminish the legal barriers that hinder or impede their achievements. The freedoms mentioned above, are access rights to the market and cannot be constituted as abuse when they are practised in a given search context for more beneficial legal or tax regimes ${ }^{34}$.

30. Nevertheless, this statement does not solely constitute as a useful instrument for explaining if a right arising from a specific regulation in UE Law can be exploited abusively. For it to be functional, a criterion or a detailed doctrine are required to determine when an abuse occurs. We must bear in mind that, in this context, hopefully the relationship between national anti-abuse rules and EU Law in the European Court of Justice maintains the same position in all fields. Therefore, in the case of a conflict, it will be necessary to ensure the basic principle runs through its jurisprudence, in other words, the unity of UE Law and its interpretation and application should be standardized ${ }^{35}$.

31. Therefore, it is fundamental to determine what is the primarily affected right to observe, given the circumstances of each case ${ }^{36}$.

32. Given the previous considerations, it is crucial to analyse the doctrine of the Court advancing to the first conceptual reference in the sentencing of Van Binbergen, in the field of freedom to provide services, in which the Court confirms that one cannot deny a Member State the right to adopt regulations aimed at preventing the practice of freedoms being used for a lender whose activity is completely, or mainly, orientated towards their territory, to avoid the professional rules that would be applicable if they

\footnotetext{
${ }^{32}$ Judgment of 26 september 2000, Commission/Belgium (Case C- 478/98) ECLI:EU:C:2000:497, para. 45; Judgment of 21 november 2001, X e Y (Case C-436/00) ECLI:EU:C:2002:704, para. 62; Judgment of 4 march 2004, Commission/France (Case C-334/02) ECLI:EU:C:2004:129, para. 27 and Judgment of 12 september 2006, Cadbury Schweppes and Cadbury Schweppes Overseas (Case C-196/04) ECLI:EU:C:2006:544 para. 50.

${ }^{33}$ A. Martín JimÉnez, "A Globalización y derecho tributario: el impacto del derecho comunitario sobre las cláusulas antielusión/anti-abuso del derecho interno", in Documentos del Instituto de Estudios Fiscales, no 7/07, 2007, p. 6.

${ }^{34}$ In this sense, V. Ruiz Almendral “ ¿Tiene futuro el test de los motivos económicos válidos en las normas antiabuso?”, cit.

${ }^{35}$ A. Martín Jiménez, "Globalización y derecho tributario: el impacto del derecho comunitario sobre las cláusulas antielusión/anti-abuso del derecho interno", cit., p. 7.

${ }^{36}$ Opinion of Mr Advocate Tesauro delivered on 23 september 1997, Safir, Case C-118/96, para. 9.
} 
were established in the territory of that state. Without ever using the term abuse, the court makes it clear that the avoidance (although the term that is used in the original version of the sentencing is to avoid ${ }^{37}$ ) of the national professional rules through an artificial appeal or anomaly of the fundamental freedoms would not be acceptable in law ${ }^{38}$. This sentence, regardless of the decision itself, reflects the first case in which the Court considers the U-turn transactions and cases of Circumvention as alleged abuse of UE Law, tackling the problem of practice of UE freedoms with the aim to avoid the EU Member States rules hoping for the implementation of more beneficial laws.

33. So, we come to establish imposing specific requirements to a subject that cannot be considered incompatible with the Treaty (in this case; professional service providers) that are motivated to apply justified professional rules for the general interest that will apply to any person established in the territory of the State where they expect to carry out the benefit, to the extent that the service provider would be free from completing these rules due to the circumstances of being established in another member State ${ }^{39}$.

34. However, the Court will thereafter conclude and confirm that when an occupation that has a completely free regime inside an EU Member State is concerned, the requirements to become a resident within that Member State constitute as a restriction that is incompatible with the Treaty. As long as it can meet the required needs of the State of destination, where the practice of professional service providers is concerned, through the use of less stringent measures. Consequently, it cannot prevent the service providers for people settled within another Member State, imposing a permanent residence request in a certain area, when the national law does not subject the service provider to any special requirements, declaring the suppression of all discriminations imposed due to nationality or residency.

35. As we can see, the Court from the start is going to leave various clear, defined, and basic aspects that will be held in the following pronouncements. On the one hand, it will not allow UE freedoms to be used abusively with elusive outcomes. Nonetheless, it will prevent the existence of restrictions or discriminations in the proper practice of freedoms imposing limits on the national anti-abusive measures. Hence, when facing the slightest doubt in the alleged analysed fact, the reaction of the Court will be extremely restrictive when ruling the existence of a possible misuse of rights.

\section{B) The abuse of law in its application of EU Freedoms}

36. As already mentioned in the previous section, regarding the practice of the freedom to provide services, the Court, in Van Binsbergen, has set a starting point in its construction of the concept of Legal abuse to confirm that the stakeholders cannot rely on UE Law fraudulently or abusively, although they restrict the law by admitting that the search for a more beneficial legal system cannot invoke to justify a general presumption of abusive practises and to serve the justification of measures that go against the practice of a fundamental freedom guaranteed by the Treaty.

37. Where the free movement of goods is concerned, the Court, in the judgement of Lecrerc, will use the literal term 'circumvention' in their concept of abusive conduct. If we pay attention to its

\footnotetext{
${ }^{37}$ Likewise, a Member State cannot be denied the right to take measures to prevent the exercise by a person providing services whose activity is entirely or principally directed towards its territory of the freedom guaranteed by Article 59 for the purpose of avoiding the professional rules of conduct which would be applicable to him if he were established within that State.

${ }^{38}$ Judgment of 26 november 1975, Coenen (Case C-39/75) ECLI:EU:C:1975:162: (...) Although, in the light of the special nature of certain services, it cannot be denied that a member state is entitled to adopt measures which are intended to prevent the freedom guaranteed by article 59 being used by a person whose activities are entirely or chiefly directed towards his territory in order to avoid the professional rules which would apply to him if he resided in that state, the requirement of residence in the territory of the state where the service is provided can only be allowed as an exception where the member state is unable to apply other, less restrictive, measures to ensure respect for these rules (para. 9).

${ }^{39}$ Van Binbergen, cit., para. 12.
} 
definition, we can see that it is further reiterated in the reference for the term 'evasion' ${ }^{40}$, as a configuring element of abuse of rights or to be more exact, in the context of analysing the precept, the configuration of the abuse of UE freedoms to achieve the application of a particular legal system. In this judgement, where the interpretation of different rules within the UE Law is analysed, particularly, the free competition in the common market with the aim to be able to assess the compatibility of one national regulation that imposes to all retailers the idea of a fixed price for the editor or the importer for the sale of books, the Court is going to pronounce confirming that it is not prohibited for Member States to adopt a similar legislation. Provided that this legislation respects other specific precepts in the Treaty, especially those that refer to the free movement of goods.

38. However, in this case, they constitute as measures that have similar effect to quantitative restrictions on imports that are prohibited by the Treaty. Those measures imposing the policy of prices for the sales of reimported books after having been previously exported to another Member State, except if there is objective information that confirms that these exported books were solely reimported to avoid the legislation. As we can see, the Court again stresses the protection of UE freedom in the debate excluding the exclusive case that objectively may exist; information that leads to the conclusion of the existence of abuse ${ }^{41}$.

39. In matters of the free movement of workers, the Court rules in the same line of argument, how we can extract the reasons set out in the judgement of Lair $^{42}$, whose argument is based on the concern of preventing certain abuses that could present themselves when there is objective data in the sense that a practice of freedoms exists with only one intention of accepting, through a brief period of activity, a certain aid system ${ }^{43}$.

40. The Advocate General TRSTENJAK ${ }^{44}$ has stated in the same way, that in the cases where concrete evidence of abuse of Law exists, we must exclude the possibility of accepting it as Rights of the European Union and as the Court of Justice exposed in the judgement of Commission/Spain ${ }^{45}$, in relation with the interpretation of the Directive 89/48, the nationals of a Member State cannot take advantage of the possibilities created by the UE Law or try to abusively avoid the application of its national legislations.

41. Nevertheless, the Advocate General POIARES MADURO ${ }^{46}$ states that one cannot conclude that an abuse of the Law exists when an EU citizen wanted to take advantage of a profession in another more advantageous Member State than that that he studied in.

42. TRSTENJAK will conclude stating that, depending on the principles of this jurisprudence, all EU citizens are permitted to practice their rights of free circulation. To guarantee that this occurs, it also corresponds with one of the objectives expressed in the first recital of the Directive 89/48: to abolish, between the Member States the obstacles of the free movement of people. Therefore, the question cannot be analysed if we are effectively facing a case of abuse of rights in the abstract, without considering the objectives of the Directive and will only be able to appreciate its existence when the citizens have not effectively or objectively practised their rights of free circulation.

\footnotetext{
${ }^{40}$ Definitions verb (tr) to evade or go around; to outwit; to encircle (an enemy) so as to intercept or capture.

${ }^{41}$ Judgment of 21 september 1983, Deutsche Milchkontor and others (Joined Cases 205/82 to 215/82) ECLI:EU:C:1983:233; Judgment of 15 may 1986, Johnston (Case 222/84) ECLI:EU:C:1986:206; Judgment of 8 february 1996, FMC and others (Case C-212/94) ECLI:EU:C:1996:40; and Judgment of 15 june 2000, Arco Chemie Nederland and others (Joined Cases C-418/97 and C-419/97) ECLI:EU:C:2000:318.

${ }^{42}$ Lair, cit.

${ }^{43}$ We find a similar line of argument in Judgment of 23 march 1982, Levin (Case C-53/81) ECLI:EU:C:1982:105; Judgment of 27 march 1985, Hoeckx (Case C-249/83) ECLI:EU:C:1985:139; Judgment of 3 june 1986, Kempft (Case C-139/85) ECLI:EU:C:1986:223 and Judgment of 3 march 1993, General Milk Products (Case C-8/92) ECLI:EU:C:1993:82.

${ }^{44}$ Opinion of Mr Advocate Trstenjak, delivered on 2 june 2010, Koller, Case C-118/09.

45 Judgment of 3 october 2008, Commission/Spain (Case C-286/06) ECLI:EU:C:2008:586, para. 55.

${ }^{46}$ Opinion delivered on 28 february 2008, Cavallera, Case C-311/06.
} 
43. Despite this, the Court is going to go one step further in configuring the concept of abuse including those with similarities to the term 'fraud' using the construction abuse of fraudulent conduct to qualify the prosecuted conduct, breaking a classic distinction between both legal concepts ${ }^{47}$.

44. In the Paletta $I I^{48}$ case, in which they argue over the validity of a certificate issued by a medical authority of a Member State (Italy), that grants economic benefits to posted workers for businesses from another State (Germany), the German national court observes that in practice the certificate attesting their incapacity to work, does not always correspond to reality, especially when they understand that they have been abusively issued or obtained. Bearing this observation in mind, the Bundesarbeitsgericht develops a line with case law in which, there is an understanding that abuse exists, an entrepreneur can contest the sincerity of the medical documents that at first show that one is unable to work, usually in a cross-border basis, meaning that the worker should bring additional proof in support of the authenticity of their inability to work. Whilst analysing the case the Court starts to establish, basing it on objective elements, that the national legal systems may consider the stakeholder's abusive or fraudulent behaviour, and in their case, to refuse them the benefits of the regulations invoked in UE Law.

45. However, the application of the jurisprudence mentioned by the national legal system, dictates that the worker must provide additional tests to support the authenticity of their inability to work by providing a medical certificate. If when the company invokes and tests the mitigating circumstances that allow serious doubt on the worker's alleged inability to work which happens unexpectedly in a Member State that differs from the competent Member State, and it does not comply with the legal system, the worker would create testing difficulties that the UE regulations were originally aimed at eliminating, as it is not proportionate for the difficulty that it entails.

46. Therefore, in this important pronouncement, the Court confirms that this conduct becomes abusive (or fraudulent) when it can demonstrate itself in such a way based on objective elements; up to now, this approach does not cause any major novelty; however, to determine reliably that such conduct exists, means that they must take into account three essential elements: firstly, that abusive behaviour carried out by investors can be determined objectively; secondly, the aims or objectives intended by the analysed rules, and thirdly, the proportionality in the burden of proof (or procedural element).

47. To be able to determine the existence of an abusive behaviour the same person based on the objective data must demonstrate their existence, using the UE freedoms to obtain a more beneficial legal regime than the one which was evaded; symmetrically, to determine the abuse of a certain rule, the aim or objective must be known, in a way that can rationally conclude that the alleged abusive behaviour effectively moves away from the aim intended by the evaded rule, and lastly, the demand of testing in the way in which the behaviour declared as abusive is protected must be provided and congruent with the UE legal system.

48. Consequently, the position of the Court is reiterated when it seamlessly confirms, that the use of UE freedoms to obtain a certain legal status or the application of a more beneficial regime, will automatically not be considered as abuse.

\footnotetext{
${ }^{47}$ In Spanish doctrine, the expression fraud of law is used to refer also to the concepts of circumvention or abuse of the norm, although this term is modified with the wording of article 15 given in the General Tax Law of 2003, referring to the expression Conflict in the application of the tax regulation: Article 15. Conflict in the application of the tax regulation.1. It will be understood that there is a conflict in the application of the tax rule when the realization of the taxable event is totally or partially avoided or the tax base or debt is reduced through acts or businesses in which the following circumstances concur: a) That, individually considered or as a whole, are notoriously artificial or inappropriate for the achievement of the result obtained. b) That their use does not result in relevant legal or economic effects, other than tax savings and the effects that would have been obtained with the usual or own acts or businesses.

${ }^{48}$ Judgment of 2 may 1996, Paletta II (Case C-206/94) ECLI:EU:C:1996:182.
} 
49. And it is clear that the conclusion that can be extracted from the present rulings is that the citizens of the Member States are permitted to carry out their rights and freedoms that the UE legal system $^{49}$ grants them, choosing the regime that will be the most beneficial, without a priori, such behaviour could be considered as abusive. It is essential that another defining element be added to the legal construction of the concept that defines abuse of rights, providing it with a material content that allows us to distinguish when we are facing an abusive practice of EU freedoms to obtain the circumvention of a certain detrimental legal regime. This element will be defined by the Court in their different rulings in matters related to the freedom of establishment.

50. The Court of Justice has confirmed repeatedly that the concept of establishment is very broad and implies the possibility that a UE citizen has a stable and continuous participation in the economic life of a Member State that is different to the State of origin, benefitting itself and encouraging the economic and social integration in respect of self-employed activities within the $\mathrm{UE}^{50}$.

51. Additionally, the freedom of establishment operates in a dual sense: on one hand, ensuring that whichever national of a Member State (whether it's an individual or a legal entity) enjoys the national treatment in the hosting State and on the other hand, ensuring that the State of origin does not obstruct one of its nationals or a company incorporated under its legislation ${ }^{51}$ in the hosting State. Therefore, in respect to the freedom of establishment it's going to limit both the policy-making capacity in the State of origin, as well as the policy-making capacity of the State of establishment. In this regard, this freedom has become fundamental in the construction of the jurisprudence, in matters of abuse of rights by the Court of Justice, as it has been about to remain patent in renowned judgements such as Cadbury Schweppes ${ }^{52}$ or Marks \& Spencer ${ }^{53}$, amongst many others.

52. One of the first complete definitions of the concept of establishment carried out by the Court we will find in its literal form in the Judgment of Factortame $I^{54}$, in which it is noteworthy that the concept of establishment involves the effective practice of an economic activity by means of a permanent installation in another Member State for an indeterminate duration. From this definition we can extract that the court understands that it is imperative in order for a real establishment of a Member State to exist, that they require a convergence of firstly, the effective and real development of an economic activity that is developed with sufficient material means and secondly, that it is developed in an indefinite amount of time, although this last requirement is arguable with regards to whether the indefinite amount of time is extensive enough to not be considered sporadic.

53. To give the answer to this argument the Advocate General DARMON, in his presented conclusions $^{55}$ in the Daily Mail case, confirmed that to understand that a real establishment exists they must have practiced an economic activity with character, which if not permanent, was at least long-lasting.

54. However, this stance has various nuances in the jurisprudence of the Court: in Centros $^{56}$, a newspaper whose main objective centres in a danish marriage, and resides in Denmark, that decides to carry out business activities in the Danish State operating as an English private limited company and fully subjected to English Law, with the intention to avoid the application of rules on minimum capital requirements in Danish Law. Because of this, and although both the effective direction of their principal place

\footnotetext{
${ }^{49}$ J. Labeaga Azcona, "La adaptación de la regulación del derecho tributario general al Ordenamiento comunitario, Comisión para el estudio de la adaptación del derecho tributario al comunitario”, Instituto de Estudios Fiscales, Madrid, 2011.

${ }^{50}$ Judgment of 21june 1974, Reyners (Case 2/74) ECLI:EU:C:1974:68.

${ }^{51}$ Judgment of 16 july 1998, ICI (Case C-264/96) CLI:EU:C:1998:370, para. 21.

52 Judgment of 12 september 2006, Cadbury Schweppes PLC (Case C-196/04) ECLI:EU:C:1998:370.

${ }^{53}$ Judgment of 13 december 2005, Marks \& Spencer (Case C-446/03) ECLI:EU:C:2005:763.

${ }^{54}$ Judgment of 25 july 1991, Factortame II and others (Case C-221/89) ECLI:EU:C:1991:320.

${ }^{55}$ Opinion delivered on 7 june 1988, Daily Mail, Case 81/87.

${ }^{56}$ Judgment of 9 march 1999, Centros (Case C-212/97) ECLI:EU:C:1999:126.
} 
of business of said company took place in Denmark, the shareholders preferred to operate under a private limited company subjected to British Law and with their registered office in England. The litigation arose when requesting the registration of a branch of said company in Denmark (a branch that, in fact, was going to be the main establishment of the company since the effective direction of the company and its principal place of business is centred there). The Danish authorities refuse this application for registration using the main argument that the company interested has their centre of economic activities in Denmark, without carrying out any economic activity in the United Kingdom and their only intention in constituting as a company under British Law, is to evade the relative Danish regulations to limited reliability companies.

55. The Court, in its decision, proceeds to point out that freedom of establishment conferred by Article 52 of the Treaty to UE nationals includes the right to take up and pursue activities as selfemployed persons, as well as when administrating and setting up companies in the same conditions as those defined by the State legislation for its own nationals; moreover, article 58 of the Treaty, equips individuals, nationals of Member States, companies constituted in accordance with the law of a Member State and whose head office, central administration is found in the European Union. It continues to affirm the fact that a national of a Member State that wants to create a company, choses to from it in another Member State whose regulations on rights of companies seem less harsh and open up branches in other Member States and cannot constitute as an abuse of establishment rights. In effect, the rights of forming a company in accordance with the Member State's legislations and creating branches in other Member States is inherent in the exercise of established freedoms that are guaranteed by the Treaty within a unique market, without requiring the first stage of protection of the freedoms analysed.

56. This argument maintains the same position that was sustained in the Segers ${ }^{57}$ case, emphasising that the national provisions from which stakeholders have sought to avoid, are rules governing the formation of companies and not rules concerning the exercise of certain activities.

57. Moreover, the provisions of the Treaty relating to the freedoms of establishment have a purpose precisely to allow companies incorporated under the Member States legislations and whose head office, central administration and principal place of business is found within the European Union, practiced through an agency, branch or subsidiary activities in other Member States.

58. The fact that a company does not practice any activity in the Member State where it has its registered office and develops its activities solely in a Member State of one of its branches is not enough to demonstrate the existence of an abusive and fraudulent behaviour.

59. Because of this, it will end up deciding that the UE system is quite clear in relation to companies that can benefit from the freedoms of establishment constituted in accordance with the legislation of a Member State and whose head office or principal place of business is found within the European Union, denying that the behaviour in question is abusive: its inherent to an integrated European market, where each state has their own system, that the operators chose the one that suits them best ${ }^{58}$.

60. However, this interpretation does not exclude the authorities of the affected Member State from adopting whichever appropriate measures to prevent or sanction fraud when they can demonstrate that, what they want from the formation of a company is to evade their obligations towards private or public creditors established in the territory of the affected Member State.

\footnotetext{
${ }^{57}$ Judgment of 10 july 1986, Segers (Case 79/85) ECLI:EU:C:1986:308, para. 13 (...) the right of establishment includes pursuant to article 58 of the eec treaty, the right of companies or firms formed in accordance with the law of a member state and having their registered office, central administration or principal place of business within the community to pursue their activities in another member state through an agency, branch or subsidiary. With regard to companies, it should be noted that it is their registered office in the abovementioned sense that serves as the connecting factor with the legal system of a particular state, as does nationality in the case of natural persons.

${ }^{58}$ Segers, cit.
} 
61. Effectively, the fact that the Court understands contrary to law, the non-recognition of the constitution of a company under the terms set forth in Centros, it does not prevent it arguing that, the society itself could constitute a wholly artificial arrangement, and also, an abusive practice of the freedom of establishment, because as they try to support the ECJ rulings on the discern between the freedom of establishment and the effective realization of a real and valid economic object in a first level of protection, it would enter in a second area of analysis.

62. In this regard, the judgement of Cadburys Schweppes is of upmost importance, and for that matter, the conclusions presented by the Advocate General LÉGER ${ }^{59}$. In this sentence, the Court will convincingly confirm that in order for a restriction on freedoms of establishment to be justified by motives in the fight against abusive practices, the specific objective of such a restriction must be opposing to consistent behaviours in creating purely artificial arrangements, of which do not reflect economic reality, and which have the objective to evade taxes normally owed by the activities that the shareholder carries out in their State of origin, also seeking to equate the activities which do not reflect economic activity such as letterbox or front subsidiaries ${ }^{60}$.

63. In a logical conclusion from the Court's arguments, it appears clearly and convincingly that the UE citizens cannot take advantage of or justify themselves in geographic mobility that guarantees them the provisions of UE rights with the sole intention of evading their respective national tax regimes. This would constitute as the abusive use of the rights of establishment that would justify restrictive measures on behalf of the national governments who aim to eliminate possible tax evasion ${ }^{61}$.

64. To define the expression wholly artificial arrangement will be, without a doubt, the essential requirement to distinguish when the stakeholder is using the practice of freedoms of establishment abusively. For this, the Advocate General LEGER considered a test based on three fundamental elements that would serve to distinguish the wholly artificial arrangements from those arrangements which aren't.

65. Firstly, it deals with the degree of physical presence of the subsidiary in the host State, secondly, the genuine nature of the activity provided by the subsidiary and, finally, the economic value of that activity to the parent company and the entire group, although the development of this test will be dealt with in depth in the next chapter of this work.

66. Therefore, from the perspective of the practice of UE freedoms, the case-law of the concept of abuse of law has been based until now and almost exclusively, on determining which circumstances UE freedoms can be considered as being used to obtain a more beneficial legal regime than the evaded, using for it artificial or anomalous resources for the fundamental freedoms without establishing a clear conceptual structure due to the synonyms that are used to define prosecuted behaviour.

67. The court exclusively focuses on determining that the practice of a right conferred by the European Union will be abusive when it's used irrationally with the intention of obtaining illegitimate profits $^{62}$ and that the UE legislation cannot extend to reach and cover abusive practices by economic operators $^{63}$.

\footnotetext{
${ }^{59}$ Opinion delivered on 2 may 2006, Cadbury Schweppes, Case C-196/04.

${ }^{60}$ Judgment of 2 may 2006, Eurofood (Case C-341/04) ECLI:EU:C:2006:190, paras. 34 y 35.

${ }^{61}$ J.M. IGLESIAS CASAIS, "No discriminación fiscal y derecho de establecimiento en la Unión Europea", Thomson-Aranzadi, Navarra, 2007, p. 223.

${ }^{62}$ L. De Broe, "International Tax Planning and Prevention of Abuse", IBFD, Amsterdam, 2008, p. 754.

${ }^{63}$ Judgment of 11 october 1977, Cremer (Case 125/76) ECLI:EU:C:1977:148, para. 21: further, it appears from the answers to the second and third questions that the scope of Regulation No 166/64 and Regulation No 171/64 must in no case be extended to cover abusive practices of an exporter in taking advantage of the flat-rate assessment in calculating the refunds especially as at the time it was not a question of adopting a comprehensive set of rules but only of creating a frame-work within which the national authorities were to regulate the market for the products in question at their own discretion.
} 
68. In conclusion, it can be confirmed that even though in the context of the practice of UE freedoms studied up until now, the concept of abuse the Court of Justice constructed does not differ in excess from the general concepts existing in the different national legal systems in the Member States, the threshold requirement in its application that the Court has structured is without any doubt, much higher than that proposed by the Member States. This which is explained by the Court is a guarantor of the UE freedoms and is a direct consequence of the existence of clear competition between states, for it not to exist, or for harmonized rules to exist, could possibly bring the eradication of forced operations that are nothing but the natural practice of UE freedoms.

\section{Synthesis of the evolution of the jurisprudence of the Court of Justice in the European Union}

69. As we have been able to confirm, the jurisprudence sustained by the Court in most of its judgements, seems to solely admit those anti-abuse rules whose aim is to dismantle artificial or abnormal behaviours without real economic substance, that have been plotted to obtain an advantage or benefit that had not existed without this abusive behaviour and that with respect to the effected analysis of the practice of UE freedoms, no abuse is made. Therefore, it is undeniable that all anti-abuse rules must determine a connection between the intended purpose of the circumvented rule and that pursued by whoever exercises their right aimed at obtaining a benefit or advantage. From what has been studied until now, we can conclude that, in general, two main stages can be seen in the jurisprudence of the Court of Justice in the European Union in the construction of the concept.

70. Firstly, the Court systematically recognises that the rights that the UE legal system confers cannot be used abusively by using different terms for them that although can bring confusion for their different content, when properly contextualized become synonyms of the same misuse of the UE legal system.

71. Because of this, it is set that UE freedoms cannot be used in an abusive (or fraudulent, evasive, elusive, or in terms of circumvention) way to obtain a certain more beneficial legal regime than that evaded, using artificial or abnormal resources. In accordance with this, the Court extends that the assessment of the existence of abuse demands the interpretation of UE Law, since they could never be considered as abusive behaviours that form part of the essential content of the recognised laws by the UE Law subjects ${ }^{64}$.

72. To determine the existence of an abusive behaviour, it must be legitimate and be covered by UE provisions, but that, in essence, strays from the purpose or the real objective of the provision that covers the behaviour facing the circumvented rule using it for abnormal or artificial resources in the practices of fundamental freedoms.

73. Subsequently, the construction of the concept of abuse of rights by the Court will reach towards the first finished formulation, or, in other words, the first test of abuse that will require the concurrence of certain elements in order to condemn the existence of an abusive behaviour. A verifiable element, formally legitimate and that is covered by the UE provisions, but that essentially strays from the purpose or the real objective of the provisions that protect the behaviour facing the circumvented rule; that in conclusion, requires the proof that these conditions have created artificially and have a purpose different to that envisaged by the rules.

74. This will require an analysis to be made case by case, both in the meaning and intended purpose of UE law and the behaviour of prudent operators that manage its affairs in compliance with legal standards and in accordance with the current commercial and economic practices in force in the sector concerned.

${ }^{64}$ A. MARTín JiMÉNEZ, "Globalización y derecho tributario: el impacto del derecho comunitario sobre las cláusulas antielusión/anti-abuso del derecho interno", cit., p. 9. 
75. A subjective element consisting in the intention to obtain an advantage from the UE rules by intentionally creating conditions to obtain it. Requiring the fact that the de facto operation or formulation that has been carried out essentially to obtain a benefit incompatible with the UE Rules. A procedural element relative to the burden of proof, that would correspond to the national administration and that must respect, at all times, the criterion of proportionality although, in more serious cases it may be permitted an investment of its own load. The inexistence of an anti-abuse UE rule means that they can be the general clauses of the regulations of the Member States may apply in the judgements of the foreseeable abusive behaviours, although, to consider them in this way, they must be absolutely compatible with their own UE system and the practice of the fundamental freedoms, in a clear consequence of the primary principal and the direct effects of it.

\section{The jurisprudential doctrine on the abuse of rights on tax matters}

\section{UE measures against abusive practices regarding tax}

76. We have discussed in this work up until now, the general policy that the European Court of Justice follows in the construction of their doctrine on anti-abuse matters, particularly referring to the practice of UE freedoms. However, it is necessary to continue the analysis, with the risk of repeating some arguments already mentioned, by briefly examining the UE anti-circumvention policy on tax matters which was implemented a few years ago with the purpose of later examining the ECJ doctrine on this practice of freedom of establishment.

77. In this sense, having also already insisted on the fight against harmful tax competition, in a Commission Communication in $2001^{65}$, it warned that the European Union must focus particularly on the practical problems for the individuals and companies that operate inside the Interior market and without a doubt this task should be accompanied by measures that help the Member States to fight against fraud and tax evasion. It cannot accept double taxation due simply to the cross-border nature of the economic activity, but by eliminating it, it must not create possibilities of tax avoidance.

78. The Commission ${ }^{66}$ is going to outline some ways of coordination and cooperation between Member States which in recent years could afford to reach their objectives in tax matters and protect their tax bases, also fulfilling their obligations that are set out under the Treaty and guaranteeing the elimination of double taxation.

79. In this regard, and in respect to the application of the provisions against tax avoidance, it considers that derived from the case law of the European Court of Justice its necessary to find the right balance between the public interest of combatting abusive practices and the necessity to avoid an exaggerated restriction of cross-border activities inside the European Union, effectively coordinating the application of anti-abuse measures in order to protect the fiscal interests of the Member States practi$\operatorname{ces}^{67}$. In this way and given that the actions against the abusive practices cover a wide range of provisions, measures and practices, some Member States apply a generic notion of anti-abuse practise based on the legislation or development of the jurisprudence, whilst others apply more specific provisions, such as those relative to controlled foreign societies or the undercapitalisation, destined to protect the national tax base against some kinds of more specific types of erosion.

\footnotetext{
${ }^{65}$ Communication from the Commission to the Council, The European Parliament and The Economic and Social Committee, Tax Policy in the European Union - Priorities for the years ahead, COM (2001) 260 final, Brussels, 23.05.2001.

${ }^{66}$ Communication from the Commission to the Council, The European Parliament and The Economic and Social Committee, Co-ordinating Member States' direct tax systems in the Internal Market, COM (2006) 823 final, Brussels, 19.12.2006.

${ }^{67}$ Communication from the Commission to the Council, The European Parliament and The Economic and Social Committee, The application of anti-abuse measures in the area of direct taxation - within the EU and in relation to third countries, COM (2007) 785 final, Brussels, 10.12.2007.
} 
80. Specific rules and regulations also exist against abusive practices, such as those that prevent the application of the credit method facing the exemption method in certain cross-border situations or those specifically directed at the passive investment in other countries ${ }^{68}$.

81. Many Member States enforce in this scope a combination of general and specific provisions, this is because the secondary legislation from the European Union does not contain proper anti-abuse laws but what they do provide is the authorization to Member States for them to develop and enforce these types of regulations in specific assumptions in a way which the Directives form the compatibility standards with them ${ }^{69}$.

82. In this policy, it has been the Directives that harmonise certain aspects of tax matters of which contain certain generic mechanisms for action against abuse of profits and rights contained in the legislation such as, for example in direct tax matters, the Directive 90/434/CEE on $23^{\text {rd }}$ July $1990^{70}$, relating to the common system of taxation applicable to mergers, divisions, transfers of assets and exchanges of shares between companies in different Member States. It provides, in its article 11.1, the possibility to deny tax benefits to those operations whose main objective is to commit a fraud or evade taxes like what is available in the Directive 90/435/CEE of $23^{\text {rd }}$ July 1990, relating to common system of taxation applicable to the parent companies and subsidiaries of different Member States in their article 1.2.

83. On the other hand, Directive $2003 / 48$ CE of $3^{\text {rd }}$ June $2003^{71}$ on taxation of savings income in the form of interest payments that, although does not contain any prediction on matters of abuse in its recital 3 stating that in accordance with Article 58 paragraph 3 of the Treaty, the provisions of tax law of Member States to combat fraud or abuse must not form a means of arbitrary discrimination nor a disguised restriction on the free movement of capital and payments defined in Article 56 of the Treaty.

84. Directive $2003 / 49 / \mathrm{CE}$ of $3^{\text {rd }}$ June 2003 relating to the common system of taxation applicable to interest and royalty payments between associates from different Member States, that collect diverse anti-abuse measures such as the contents in article 1.4, relating to the clause of the beneficial owner and article 1.10, relating to the minimum period of stay. And lastly, mentions their article 4 that establishes certain causes for exclusion of payments as interest or royalties and in article 5 that contains a specific clause on matters of abuse.

85. On $28^{\text {th }}$ January 2016, the Commission presented its proposal for an Anti-Tax Avoidance Directive as part of the Anti-Tax Avoidance Package. On $20^{\text {th }}$ June 2016, the Council adopted the Directive (EU) 2016/1164 laying down rules against tax avoidance practices that directly affect the functioning of the internal market. In order to provide for a comprehensive framework of anti-abuse measures the Commission presented its proposal on $25^{\text {th }}$ October 2016, to complement the existing rule on hybrid mismatches. The rule on hybrid mismatches aims to prevent companies from exploiting national mismatches to avoid taxation. In addition to the proposal the Commission also published its Staff Working

\footnotetext{
${ }^{68}$ For example, Until the adoption of Law 540 of 29 April 2015, no general statutory rule to combat abuse existed in Denmark. However, case-law developed the 'reality' principle, under which taxation must be determined on the basis of a specific assessment of the facts. This means in particular that artificial tax arrangements may, depending on the circumstances, be set aside so that taxation takes account of reality, under the principle of substance over form. Case-law has also developed the 'rightful income recipient' (rette indkomstmodtager) principle. This principle is based on the fundamental provisions relating to taxation of income, set out in Paragraph 4 of the statsskatteloven (Law on State tax), which have the effect that the tax authorities are not obliged to accept an artificial separation between the income-generating undertaking or activity and the allocation of the income deriving therefrom. This principle is therefore intended to determine the person who - regardless of formal appearances - is the real recipient of certain income and thus the person who is liable for tax on it.

${ }^{69}$ F.A. Garcia Prats, "Las medidas tributarias anti-abuso y el derecho comunitario", in Serrano/Soler (Dirs.), Las medidas anti-abuso en la normativa interna española y en los convenios para evitar la doble imposición internacional y su compatibilidad con el Derecho Comunitario, Instituto de Estudios Fiscales, Madrid, 2002, p. 185.

${ }^{70}$ DO L 225, 20 august 1990.

${ }^{71}$ DO L 157, 26 june 2003.
} 
Document. The Anti-Tax Avoidance Directive contains five legally binding anti-abuse measures, which all Member States should apply against common forms of aggressive tax planning.

86. With everything from the analysis of anti-abuse rules contained in the Directives it can be concluded that aim to define the application of national anti-abuse provisions, anticipating that they cannot practice the laws and profits contained within them when their practice, apart from being the standard objective, is to carry out their practice with abusive intent, collecting this idea in the doctrine of the Court expressed in such important matters, in these effects such as Halifax ${ }^{72}$ or Cadbury ${ }^{73}$, authorising these national rules that continue to avoid purely artificial arrangements or that restrict the abusive use of UE freedoms, as we will conclude further on in this work.

\section{The fight against abusive practices such as justification of tax discriminatory or restriction of freedom of establishment rules}

87. As we have had the opportunity to confirm the fact that investors cannot take advantage of UE rights abusively or fraudulently, constitutes an axiom that the Court of Justice of the European Union has maintained in all its declarations. A contrario sensu, the simple practice of UE freedoms in the search for beneficial legal regimes cannot invoke to justify a general presumption of abusive practices and serve as justification as measures that go against the practice of a fundamental freedom guaranteed by the Treaty, in which the balance between the practices of rights derived from the UE system and, especially against abuse of fundamental freedoms, form the core of the abuse doctrine of the Law of the Court.

88. The Member States must reach their objectives in fiscal matters and with the aim of protecting their tax revenues, may resort to the application of anti-abuse measures to prevent erosion through the practice by stakeholders, whose freedoms and rights are protected under the Treaty of the European Union. Moreover, the need to preserve the balance in the distribution of the Court's power between Member States may also serve to defend the validity of internal fiscal regulations against abusive practices that search to protect national tax bases against those behaviours of the subjects that could cause its erosion, or a transfer of them towards other more advantageous tax jurisdictions. ${ }^{74}$

89. However, it must always be done by fulfilling the obligations under the Treaty and guaranteeing the compatibility of their national rules with the UE system, these anti-abuse measures configure as specific legal propositions that in certain assumptions apply a specifically more onerous regime, with the objective to avoid or make tax avoidance less appealing ${ }^{75}$ could eventually produce a restriction on some of the UE freedoms or a situation of discrimination.

90. Effectively, the application of the anti-circumvention rules may lead us to the existence of an obstacle to the effective attainment of the internal market and therefore, on the basis that UE freedoms constitute as an essential point of reference in its construction, while they configure as access rights to it, there is no doubt that the more they expect to avoid abusive conduct, they may constitute an obstacle to market access.

91. In this sense, and in respect to the application of the provisions against tax avoidance, one of the mechanisms for analysing the admissibility of national anti-abuse tax rules against the free practice

\footnotetext{
${ }^{72}$ Judgment of 21 february 2006, Halifax (Case C255/02) ECLI:EU:C:2006:121.

${ }^{73}$ Cadbury Schweppes, cit.

74 J.M. Iglesias CASAis and N. Lobato Mosquera, "La vigencia del principio de territorialidad fiscal como mecanismo corrector de la extensión de las libertades comunitarias a los sistemas fiscales de los Estados miembros", in Documentos $\mathrm{n}^{\circ}$ 9/2013, Instituto de Estudios Fiscales, Madrid, 2013.

${ }^{75}$ R. SAnz Gómez, "Las cláusulas anti-abuso específicas tributarias frente a las libertades de circulación de la Unión Europea”, cit., p. 21.
} 
of rights designed under the UE acquis which on one hand constitutes as the teleological interpretation of the UE's own freedoms and the secondary UE law, and on the other hand, as the existence of causes of justification of the existence of a restrictive or discriminatory treatment with regards to the practice of such rights and freedoms.

92. Because of this, it's necessary that the Court carries out a thorough analysis of the causes of justification that allow such measures that at the start may be qualified as discriminatory or restrictive, may be declared compatible with the UE legal system.

93. As we have already mentioned, the Court has had the opportunity to express that the need to avoid tax evasion cannot justify a discriminatory or restrictive treatment of the fundamental freedoms but that they can only admit such measures if, on the basis of rule of reason ${ }^{76}$, they are justified for a matter of overriding general interest being obliged that their application is suitable to guarantee the completion of the intended purpose and not go beyond what is necessary to achieve it ${ }^{77}$.

94. Thus, their way of thinking will begin by analysing if it produces a restriction of a fundamental freedom or if there has been a discriminatory effect and in this respect, the distinction of the assumptions of discrimination and restriction has been the subject of an interesting doctrinal reflection: whilst discrimination implicates the essential comparison of two diverse situations that, such as, IGLESIAS CASAIS confirms, takes as its starting point the distinction between residents and non-residents, so that the diversity of tax treatment between the two is fully justified on the basis that both are in no comparable situations ${ }^{78}$, the restriction does not require such comparison, but a simple analysis of whether the measures in question suppose an obstacle for the achievement of a UE freedom. This distinction would implicate that the way of reasoning should be different treating one or another question, as evidenced by Advocate General GEELHOED in his findings in the Test Claimants in the Thin Cap Group Litigation ${ }^{79}$ case, although what is certain is that, despite the doctrinal distinction, this has not had too many implications in the jurisprudence of the Court.

95. Therefore, to carry out a thorough analysis on the substantial differences between the concepts restriction and discrimination is not relevant to this study, particularly when the Court usually alludes to expressly describe a measure as discriminatory ${ }^{80}$ and this can be understood as a waiver to apply this distinction in tax matters.

96. However, what is of interest to our study is, as we announced at the beginning of this section, the fact that the Court recognises the possibility to restrict the fundamental freedoms in cases of abuse, and from this perspective, the freedom that has had its greatest impact on the legal systems in the Member States is, without a doubt, the freedom of establishment, because it is built on the most relevant case law, that is being studied in the present work. In the words of the Court the concept of establishment, in the sense of the Treaty, is very broad and implies the possibility that a UE citizen has a stable and continuous participation in the economic life of a different Member State than the hosting State, and that it benefits from favouring economic and social interpenetration within the UE in the field of selfemployment activities ${ }^{81}$.

${ }^{76}$ E. Rотн, "The Rule of Reason Doctrine in European Court of Justice Jurisprudence on Direct taxation”, in Canadian Tax Journal / Revue Fiscale Canadienne, vol. 56, nº 1, 2008, pp. 73 y 74.

77 Judgment of 30 november 1995, Gebhard (Case C-55/94) ECLI:EU:C:1995:411, para. 37; Judgment of 15 may 1997 , Futura Participations and Singer (Case C-250/95) ECLI:EU:C:1997:239, para. 26; Judgment of 11 march 2004, de Lasteyrie $d u$ Saillant (Case C-9/02) ECLI:EU:C:2004:138, para. 49.

${ }^{78}$ J.M. IgLESIAS CASAis, "No discriminación fiscal y derecho de establecimiento en la Unión Europea”, cit., p. 65.

${ }^{79}$ Judgment of 13 march 2007, Test Claimants in the Thin Cap Group Litigation (Case C-524/04) ECLI:EU:C:2007:161 and Opinion delivered on 29 june 2006.

${ }^{80}$ V. Ruiz Almendral, "Tax avoidance and the European Court of Justice: ¿What is at stake for European general Anti-Avoidance Rules?”, in Intertax, vol. 33, nº 12, 2005, p. 569.

${ }^{81}$ Gebhard, cit., para. 25. 
97. This agreement on the basic content of the freedom of establishment was already raised by the Advocate General DARMON, in his findings ${ }^{82}$ in the Daily Mail case, where established that the concept of establishment itself is essentially an economic one and it always implies a genuine economic link. The transfer of the central management and control of a company, understood by reference to criteria which are more economic than legal is covered by the right of establishment in so far as it is necessary to determine in concrete terms the economic centre of gravity of the undertaking. Thus, the concept of central management and control corresponds not merely to the physical location of the principal administrative services but also, and perhaps principally, to the place from which the company is actually run. The real head office is normally the place where the company' $s$ central management and administration is located, since that is the place in which the decisions concerning the company's independent activity are made and from which that activity is set in motion; in other words, it is the centre from which that activity is exercised. For the first time, it is stated that establish oneself is to integrate in a national economy through two basics aspects that are the physical settlement and the practice of an economic activity, both with character, which if not permanent will at least be long lasting.

98. According to IGLESIAS CASAIS, the substance of the freedom of establishment can be summarised firstly in a mandate of non-discrimination or national treatment of the citizens from Member States, that guarantees them the application of the same conditions that apply to nationals, in the access to the practice of a non-paid activities when they want to establish themselves in another Member State and secondly in the prohibition of existence of whatever restriction or obstacle to its practice based on the nationality or residence that derives from the application of the internal provisions of the Member States, the enforcement of rules of non-public nature which is intended to regulate self-employment collectively and the provision of services and, finally, those resulting from administrative practices ${ }^{83}$.

99. Thus, once the substantive content of freedom of establishment is defined, we then need to consider what is the reasoning of the Court to determine when we are facing an abusive practice of said freedom or, in other words, when can a national anti-abuse rule that is restrictive or discriminatory be considered justified in accordance with UE law, for the practice of that freedom of establishment. To do this, as we move to the beginning of this paragraph, the mode of reasoning by the Court will begin by analysing if it produces a restriction of a fundamental freedom or if there has been a discriminatory effect in understanding that there is no doubt on the cross-border nature of the matter.

100. The line of reasoning followed that is explained clearly in the following quote from Centros: the national measures that may hinder or make the practice of fundamental freedoms guaranteed by the Treaty less appealing, must bring together four requirements: they must be applied in a nondiscriminatory manner, that are justified by a matter of overriding general interest that is suitable to ensure attainment of the objective that they pursue and not go beyond what is necessary to achieve that objective $^{84}$. That is to say, the proportionality involves the adaptation of means to its aims, the suitability of the instruments used, and its character needed and limited to achieve the objective in question.

101. In this line, the Court shall verify compliance with this requirement, a test of compatibility of the anti-abuse rule with the UE system named rule of reason or simply and plainly, test of abuse that in its first expression, will analyse if the objective pursued by the quoted anti-elusion rule is legitimate and congruent with the ultimate goal (that must be, without any doubt, a motive of general interest).

102. In the Cadbury ${ }^{85}$ case in which it is subject to question the compatibility with UE law of specific legislation on so-called controlled foreign companies, the UK Government shall support that

\footnotetext{
${ }^{82}$ Opinion delivered on 7 june 1988, Daily Mail, Case 81/87.

${ }^{83}$ J.M. Iglesias Casais, "No discriminación fiscal y derecho de establecimiento en la Unión Europea”, cit., p. 133.

${ }^{84}$ Centros, cit., para. 34.

${ }^{85}$ Cadbury Schweppes, cit., para. 51, leaning on ICI, cit., para. 26; Judgment of 12 december 2002, Lakhorst-Hohorst (Case C-324/00) ECLI:EU:C:2002:749, para. 37; de Lasteyrei du Saillant, cit., para. 50, and Marks \& Spencer, cit., para. 57.
} 
this rule has the objective to fight against a special form of consistent tax evasion in which a resident company artificially transfers profits from a Member State in which they have been obtained, to a State with a reduced level of taxation through the creation of a subsidiary and the attainment of operations destined mainly to effect that transference of profits of the subsidiary.

103. The Court, giving answer to the UK's approach, shall admit that effectively, a national measure that restricts the freedoms of establishment can be justified where it specifically targets wholly artificial arrangements aimed at circumventing the application of the law of the Member State concerned.

104. As we can see, the demand for a specific object that is legitimate, and is congruent with overriding public interest entails a first proper exam in which the Court strictly applies; it has systematically rejected the argument of the existence of a risk of fraud or evasion, or including the aim of assuring or protecting the tax revenue, to accept restrictive or discriminatory anti-elusive measures, as we can observe In ICI when it establishes that it must note that the decrease of taxes resulting not among the reasons mentioned in the article 56 of the Treaty and cannot be considered as an overriding public interest that can be invoked to justify unequal treatment in principle incompatible with Article 52 of the Treaty ${ }^{86}$.

105. They will, among others, be the principle of fiscal territoriality, to base it on what different countries build their tax system on, the need to ensure fiscal coherence ${ }^{87}$ in other words, there unity between the measures and the intended aims in the regulations of each tribute, the need to preserve the balance allocation of taxing rights ${ }^{88}$ the need to guarantee the efficiency of the tax controls ${ }^{89}$ and the fight against abusive practices derived from the practice of UE freedoms (or the rights of the European Union) the causes of justification of the adoption of measures that can be characterised as restrictive or discriminatory that the Court has supported repeatedly ${ }^{90}$.

106. As we have had the opportunity to define the simple practice of UE freedoms, in the search for a more beneficial legal regime it cannot be invoked to justify a general presumption of abusive practise and serve as justification to measures that go against the practice of a fundamental freedoms guaranteed by the Treaty, however these must pursue, without any room for doubts, the defence of an overriding public interest that is considered compatible with the UE system.

107. The second analysis consists of studying if the anti-abuse measure adopted is suitable to attain the legitimate objective pursued. Continuing with the Cadbury case, the Court refers to it in paragraph 59 in the sentencing to affirm that by providing for the inclusion of the profits of a CFC subject to [a] very favourable tax regime in the tax base of the resident company, the legislation on CFCs makes it possible to thwart practices which have no purpose other than to escape the tax normally due on the profits generated by the activities carried on the national territory. (...) Such legislation can achieve, therefore, the purpose for which it was adopted.

108. The States have the tendency to configure anti-abuse rules with the widest possible scope in a legitimate protectionist framework in their fiscal interest, but what becomes evident is that the Court

\footnotetext{
${ }^{86} \mathrm{ICI}$, cit., para. 28.

${ }^{87}$ Judgment of 28 january 1992, Bachmann (Case C-204/90) ECLI:EU:C:1992:35, Commission/Bélgium, cit., and Judgment of 23 october 2008, Krankenheim Ruhesitz am Wannsee-Seniorenheimstatt (Case C-157/07) ECLI:EU:C:2008:588.

${ }^{88}$ Judgment of 29 march 2007, Rewe Zentralfinanz (also known as Cassis de Dijon) (Case C-347/04) ECLI:EU:C:2007:194, Judgment of 18 july 2007, Oy AA (Case C-231/05) ECLI:EU:C:2007:439, Judgment of 8 november 2007, Amurta (Case C-379/05) ECLI:EU:C:2007:655 and Judgment of 18 june 2009, Aberdeen (Case C-303/07) ECLI:EU:C:2009:377.

${ }^{89}$ Futura Participations and Singer, cit., para. 31, and Judgment of 8 de july 1999, Baxter and others, Case (C-254/97) ECLI:EU:C:1999:368, para. 18.

${ }^{90}$ Judgment of 28 january 1992, Bachmann (Case C-204/90) ECLI:EU:C:1992:3, Judgment of 19 april 2000, Baars (Case C-251/98) ECLI:EU:C:2000:205, Judgment of 18 September 2003, Bosal (Case C-168/01) ECLI:EU:C:2003:479, EmslandStärke, cit., and Opinion delivered on 7 april 2005, Halifax case.
} 
does not accept, under any circumstances, that these rules have an expansive character. The irrebuttable presumptions in law abuse are rejected by generalists or deemed inadequate to achieve the intended purpose that is simply to prevent the misuse of freedoms and UE rights without such a goal, it could dislodge a restriction, which would threaten its practice. In short, it's about analysing if being able to declare a national rule as restrictive or discriminatory, however there may be reasons to justify such a statement as compatible with the law.

109. Finally, the submission of the national anti-abuse legislation on the principal of proportionality assumes that the final step of analysis that the Court takes in the measure in question is to determine whether it is compatible with UE law. This principal presupposes the existence of two interests that are relevant to the legal system and that are found in conflict, being the objective of this principal to fulfil one of the interests in the way that least affects the other, always in the subject of a concrete case ${ }^{91}$; in such a case, not only must the application of the anti-abuse measure be suitable to guarantee the attainment of the intended purpose, but also, must not go what is beyond necessary to achieve it. Elements such as the burden of proof, establishing reasonable presumptive criteria, the permeability of the rule admitting exceptions to its application or fulfilment of its judgement of necessity involve a balance of proportionality between the stakes, based on this, we will take a closer look in the following sections of this paper. In conclusion, whichever measure adopted by the Member State that constitutes a restriction to the freedom of establishment, or produces a discriminatory effect is initially prohibited by the Treaty in the measure in which makes the practice of that freedom less attractive.

110. However, as deduced from the case law from the Court of Justice that it may admit a restriction to the freedom of establishment if it is justified by matters of overriding general interest being accurate and, moreover suitable to guarantee the attainment of the intended purpose and that does not go beyond what is necessary to achieve it.

111. In this sense, a national measure restricting freedom of establishment may be justified where it specifically targets wholly artificial arrangements aimed at circumventing the application of the law of the Member State concerned, and in order that a restriction on freedom of establishment can be justified on the grounds of prevention of abusive practices, the specific objective of such a restriction must be directed to oppose consistent behaviours on creating wholly artificial events, which do not reflect economic reality and with the sole objective to avoid the taxes that are normally due from the profits generated from activities carried out in national territory.

112. As we have already mentioned, the Commission ${ }^{92}$ has already advised that the European Union must centre itself particularly in the adoption of measures that help the Member States to fight against fraud and tax evasion. The needs to prevent abusive practices or tax evasion can constitute as a matter of overriding general interest capable of justifying a restriction on fundamental freedoms. Without losing sight at any moment that the starting point of the Court, in the cases in which they analyse abuse of rights, is the proportionality between the adopted anti-abuse measure and the possible harm to be avoided, the legitimacy of the restrictive rules is conditioned precisely to the compliance with the principle of proportionality, moreover that these rules apply especially with the aim to avoid wholly artificial arrangements ${ }^{93}$.

\footnotetext{
${ }^{91}$ R. SANZ GómEz, "Las cláusulas anti-abuso específicas tributarias frente a las libertades de circulación de la Unión Europea”, cit., p. 127.

${ }^{92}$ COM (2001) 260 final.

${ }^{93}$ Opinion of the European Economic and Social Committee on the Communication from the Commission to the Council, the European Parliament and the European Economic and Social Committee - The application of anti-abuse measures in the area of direct taxation — within the EU and in relation to third countries, COM (2007) 785 final, 2009/C 77/29, Brussels, 2009.
} 


\section{A) Factual situations that invoke the fight against abusive practices in taxation as justification}

113. We have insisted throughout this work in the idea that the employment of UE freedoms to achieve the application of a certain legal regime is not in itself abusive, and that to achieve it, the Member States' anti-circumvention rules must be assessed with the necessary prudence. Moreover, in this respect a case analysis must be carried out in which it does not rule out that circumvention may ultimately be legitimate from the perspective of the UE legal system.

114. Therefore, analysing the tension that occurs between the interest of the Member States and the UE legal order, through the factual circumstances in which mainly fight against abusive practices, and involves a practical exercise, which is not limited in its analysis, and may help to clarify the position taken by the Court. If they examine the sentences in which the matter of freedom of establishment is invoked in the application of a national restrictive or discriminatory anti-circumvention rule of such freedom, we find that it results in some very concrete factual assumptions.

115. Firstly, through the creation of companies in different Member States with lower taxation (or creation of foreign subsidiaries by SEC), the international fiscal transparency system aims to produce an erosion of tax bases, either by the transfer of the profits of the parent to that other company incorporated in the hosting state or by practices that constitute in organising transfer of losses within a group of companies, to established companies in the Member States that apply the highest rates of taxation, and consequently, where the tax value of these losses is greater, which can result in impairing the rights of the Member States to practice their fiscal competition in relation with the activities carried out in their territory and therefore jeopardise the balance in the allocation of taxing rights between Member States.

116. A clear example of this is analysed in Cadbury, where the Court will have the opportunity to examine the compatibility with the UE Law of a national regime relative to SEC and its aim is to fight against tax evasion and the consistent practice in which a company with residence in a Member State transfers its taxable profits to a company which it controls that's deployed in another State, that applies a tax rate well below the current one applied in the State of origin.

117. The question is based on determining if by constituting a company in another Member State with the sole basis of the existence of a more favourable tax regime in that State, is practising the fundamental freedoms or on the contrary, if it constitutes an abuse of said freedoms: the national legislation on SEC on this matter is contracted to the fact that a foreign subsidiary, in which the parent company has a superior participation of $50 \%$, is treated like a transparent entity and therefore it attributes to the profits of the branch to the parent company and included in the tax base of the latter, although the latter was not noticed.

118. This legislation applies when the subsidiary established in another State is subject to a lower level of tax in this other State, so the intent of the legislation is to ultimately determine if the fact that a parent company created this subsidiary in another Member State in order to qualify for a more favourable tax regime, constitutes in itself as an abusive practice of the freedom of establishment.

119. The Court has reiterated, firstly, that a Member State cannot prevent a company from exercising its right of establishment in another Member State on the basis that the transaction would result in a tax loss with respect to taxes that would have been payable due to future activity if the company had practiced that activity in their home state. Similarly, the mere fact that a resident company establishes a secondary establishment in another Member State cannot form a general presumption of fraud or tax evasion and justify a measure which compromises the exercise of a fundamental freedom guaranteed by 
the Treaty ${ }^{94}$ and the establishment of a company in another Member State does not imply tax evasion, while the company concerned is however, subject to the law of that State ${ }^{95}$.

120. Finally, it can also be deduced from the case law that a Member State cannot hinder the exercise of freedom of movement in another Member State under the pretext of the reduced level of taxation ${ }^{96}$. The Court is not going to argue the rights of a company to rely on the protection conferred by the Treaty, as far as the exercise of freedom of establishment is concerned, even when it's only practiced with the aim of remaining a subject of a more favourable tax regime. Where it will set the threshold for justification of national anti-abuse measure is actually in the analysis of whether the subsidiary has a real and effective activity in the hosting State. The tax level constitutes an element that can legitimately bear in mind a company at the time of choosing a hosting State, in which it plans to create a subsidiary, being able to decide to practice its secondary activities in another Member State to benefit from the more favourable fiscal regime in this other State with regards to the taxation of taxable activities.

121. However, a national measure that restricts the freedom of establishment can be justified when it specifically targets wholly artificial arrangements whose aim is to circumvent the legislation applied by a Member State that specifically targets this concept of wholly artificial arrangement like the practices mentioned in Marks \& Spencer ${ }^{97}$, that consists of organising transfer of losses within a group of companies to companies established in the Member States that apply high rates of tax and consequently where the tax value of these losses is higher, in which the Court will without a doubt impair the rights of the Member State to practice its tax competition in relation with the activities carried out in its territory and jeopardise the balance in the allocation of taxing powers.

122. Similarly, the ECJ in Test Claimants in the CFC and Dividend Group Litigation when it confirms that in those circumstances, in order for the legislation on CFCs to comply with UE law, the taxation provided for by that legislation must be excluded where the incorporation of a CFC reflects economic reality, despite the existence of tax motives. That finding must be based on objective factors which are ascertainable by third parties with particular respect to the extent to which the CFC physically exists in terms of premises, staff and equipment ${ }^{98}$.

123. Therefore, and although later we will take a closer look on the notion of wholly artificial arrangements to widen your understanding, we can conclude that the Court in the matters in which it had the opportunity to analyse the cases of international tax transparency, maintains the reasoning for which it understands that the UE legal system opposes the inclusion of a tax base of a company with residence in a Member State with profits obtained by a foreign company controlled by another Member State, when these profits are subjects in the latter State with a lower taxation level to that applied in the first State, unless such an inclusion only concerns those purely artificial arrangements destined to circumvent the national tax that's normally due.

124. This limitation does not compromise the application of the rules on the prices of transfers, granted that it must be in keeping within this section for its necessary natural identity because it must serve to address non-trade agreement prices between related companies. Therefore, the SEC rules must have the utility to complement the relative rules for determining the residence of a company, or the prices of transfer, in the measures that constitute an instrument to combat the types of artificial fiscal operations.

\footnotetext{
${ }^{94}$ Commission/Belgium, cit. para. 45.

${ }^{95}$ Judgment of 8 march 2001, Metallgesellschaft and others (Joined Cases C-397/98 and C-410/98), ECLI:EU:C:2001:134, para. 57, and Lankhorst-Hohorst, cit., para. 37.

${ }^{96}$ Opinion of Mr Advocate Leger delivered on 2 may 2006, Cadbury.

${ }^{97}$ Marks \& Spencer, cit., para. 49.

${ }^{98}$ Order of the Court (Fourth Chamber) 23 April 2008, Test Claimants in the CFC and Dividend Group Litigation, Case C-201/05, apartado 79 .
} 
125. A second assumption that constitutes the undercapitalisation that is defined as an evident disproportion between the magnitudes of the responsibility of fixed, legal or statutory capital, and the level of financial risk of a company. The design of undercapitalization rules has been approached from many different perspectives, reflecting the different mentalities and legal traditions in the Member States, even though the background is very similar, if not identical: between the alternatives of finance that the companies have within their reach, they can turn to equity through loans or through capitalisation, bearing in mind that these alternatives, from a tax perspective, are not perfect alternatives, although while external funding generated in taxation has the possibility of deductibility of interest paid, a company decides to obtain resources through their own (internal) funding not only will they lose this deductibility but could also generate problems of double taxation (taxation of dividends or share in profits).

126. In that regard, and to avoid the internal funding generating losses of tax deductibility, the entities of multinational groups can have as an option the granting of loans within the entities of the group that are generating a certain margin of action to select the taxing of the diverse entities, in a way that those whose residence for tax purposes is located in a country with a higher rate of tax is in debt with entities with residence in areas of lower taxation.

127. The different treatment between debt and equity financing under national tax law (and at bilateral level), resulting in the taxing rights on the hosting State being generally more limited than those on dividends, making debt financing considerably more attractive in cross-border context and can therefore lead to the erosion of the tax base in the state of the subsidiary. By abolishing their thin cap rules altogether or by carving out dealings with lenders resident in other MSs and EEA States, the difference in treatment between resident subsidiaries according to the seat of their parent company within the EU/ EEA would be removed.

128. The Commission is of the opinion that Member States should, however, be able to protect their tax bases from artificial erosion through structured debt financing, also within the EU/EEA. Following Lankhorst, some Member States have tried to avoid the charge of discrimination by extending the application of their thin cap rules to cover also purely national relations ${ }^{99}$.

129. In that case, the German company Lankhorst-Hohorst GmbH (henceforth Lankhorst-Hohorst) whose sole shareholder was the company Lankhorst-Hohorst BV (henceforth LHBV), based in the Netherlands has as its sole shareholder of the company, the Dutch company Lankhorst Taselaar BV (henceforth LTBV). LTBV granted a loan to Lankhorst-Hohorst to be returned in ten years with a variable interest rate and that would serve as an alternative to the increase in capital, being accompanied by a statement of sponsorship of which LTBV would renounce the loan repayment if third-party creditors sued Lankhorst-Hohorst. The loan allowed Lankhorst-Hohorst to reduce another loan that they had concerted with the banking establishment AMRO-Bank Münster, and therefore reduce the interest charges that withstood. In their liquidations of tax assessments on companies corresponding to the 1997 and 1998 practices, the tax authorities considered the interest payments to LTBV as equivalent to a distribution of profits and subjected them to such taxes.

130. The German, Danish and UK Governments, as well as the Commission, argue that the national provision at issue in the main proceedings is intended to combat tax evasion to which would lead to the use of the mechanisms such as thin capitalization or undercapitalisation and, all other things being equal, it would be fiscally advantageous to finance a subsidiary through a loan rather than through capital contributions, as profits of the subsidiary to the parent company are transferred to the parent company in the form of deductible interest upon the calculating taxable profits of the subsidiary, not in the form of non-deductible dividends. The Court, however, will not allow such allegation and will keep influencing

${ }^{99}$ COM (2007) 785 final, cit., p. 8. 
in the decrease of tax revenue, not constituting as an overriding reason relating to public interest that can justify a contrary measure for a fundamental freedom ${ }^{100}$.

131. Where the justification relating to risk of tax evasion is concerned, it should be noted that the disputed rules in the main litigation do not have a specific aim to exclude from a tax advantage the wholly artificial arrangements but that in general, contemplate whichever situation in which the parents company has, no matter what the motive, their domicile outside the Federal Republic of Germany, and so this situation does not imply a risk of tax evasion, as the company in question will be subject in every way to the tax legislation of the State of establishment. Moreover, the national Court does not consider the existence of any abuse in this case, as the loan is attained to reduce the burden of the amount of interest resulting from their bank credit and released the documents before the Court which showed, that during 1996 and 1998 financial years, Lankhorst-Hohorst suffered substantial losses much higher than the interest paid to LTBV.

132. Therefore, despite the facts analysed, Lankhorst-Hohorst meets all benchmarks for the use of the mechanism thin capitalization. For it to be considered abusive by the Court it must exceed the triple test to which the legislation is submitted, but this is not enough to determine the existence of the mechanism for it to be considered unlawful.

133. In this regard, in the judgement Test Claimants in Thin Cap Group Litigation the ECJ confirmed that certain measures used to avoid undercapitalisation were not unacceptable by still being needed to limit their application in wholly artificial arrangements. This could guarantee that the conditions of the operations of debt financing arrangements between affiliates do not exceed the limits of what unrelated parties would have agreed on based on valid commercial reasons.

134. The Member States cannot make their fiscal systems work efficiently unless they can guarantee that their tax bases do not suffer erosion due to the agreements in non-commercial terms between related companies. So, in that case a national legislation is analysed which restricts the ability of a resident company to deduct interest on loan finance for tax purposes, which has been granted by a parent company with residence in another Member State, the reason for this, is to fight against abusive practices and especially against wholly artificial arrangements solely used for tax purposes.

135. A law on thin capitalization rules is judged containing provisions that occasionally restrict the deductibility of interest paid by subsidiaries to non-resident companies. Logically, this measure does not apply if the payment was between residents. The part of the interests that exceeds a reasonable economic performance is not deductible from the taxable profits of the borrowing company but is treated as distributed profit (dividend); likewise, at a later point they will reassess the interests paid between companies of the same group as distributed profit, as far as they exceeded what would have been paid in the absence of a link between paying the interest and the beneficiary.

136. In this matter the Court starts to accept that, within a group of companies, the risk that the finance of a subsidiary provides a way that produces a transfer of profits towards the State with a lower tax rate, does not normally exist if all the companies are subject to the same rate of tax in the same Member State. However, this does not exclude the fact that the rules adopted by a Member State to specifically consider the cross-border group situation, can in some cases constitute as a restriction of freedom of establishment for the companies involved.

137. In that case, to consider that such a legislation constitutes a restriction on the freedom of establishment, to such a degree that it can restrict the practice of this freedom in a Member State through

${ }^{100}$ ICI, cit., para. 28, Metallgesellschaft and others, cit., para. 59, and Judgment of 21 september 1999, Saint-Gobain ZN (Case C-307/97) ECLI:EU:C:1999:438, para. 51. 
established companies in another Member State, without having to prove that the legislation involved led to some of those companies to refrain from acquiring, creating or maintaining a subsidiary in the first Member State. From this, it results that the difference in treatment to which they are subjected to under the controversial national provisions in the main proceedings relating to thin capitalization, and resident borrowing companies based on the place of residence of the affiliated company lender, constitutes a restriction of freedoms of establishment.

138. The fact that a resident company has obtained a loan from a non-resident company under conditions that do not correspond with what the companies involved would have agreed to in free competition conditions constitutes for the Member State of residence of the borrowing company an objective element and verifiable by third parties to determine if the transaction involved constitutes, totally or partially, a wholly artificial arrangement whose main objective is to avoid the court legislation in this Member State. In this respect, it is whether in the absence of a special relationship between the companies in question, they would not have agreed to the loan or would have agreed on a different rate of interest.

139. In further points out that, at first, it is completely valid, and, in reality, crucial that the taxpayer tries to organise their cross-border fiscal situations advantageously for the idea of an internal market. However, this by itself is allowed in the measure in which such an organisation conforms to reality: in other words, there is no question of a purely artificial arrangement designed to abuse the national tax legislation or evade.

140. In this sense the European Court will settle admitting that, if the mere circumstance that a resident company obtains a loan from an associated company established in another Member State it cannot invoke to justify a general presumption of abusive practices, nor serve as a justification to a measure that goes against the practice of a fundamental freedom guaranteed by the Treaty ${ }^{101}$, a rule such as that may be compatible with the legal system if: on one hand, this legislation is based on a consideration of objective and verifiable elements that identifies the existence of a wholly artificial arrangement solely for tax purposes. To do this, you must establish the possibility that the taxpayer may submit, where applicable, and without being subject to undue administrative constraints, evidence for the underlying commercial reasons for the transaction; and on the other hand, if the existence of such assembly is demonstrated, such legislation only labels these interests as distributed profits to the extent to which they exceed what would have been agreed under the conditions of free competition.

141. Therefore, the detection of a wholly artificial arrangement thus amounts in effect to a substance-overform analysis and even though there are few sentences that directly address configuration of thin capitalisation rules ${ }^{102}$, the conclusion that may be drawn from this is that it is possible that the existence of these rules is perfectly compatible with the UE system as long as the rule allows the substanceoverform analysis and the mere fact that the constitution of a loan (or another credit operation) between related parties does not involve a presumption of objective fraud. However, the coherence of the fiscal system could justify the anti-capitalization rule since it is incardinated to the correct formation of the taxable income tax and equity in the distribution of tax revenues between the state in which investment and residence occur.

142. The Court of Justice demands the existence of a direct link, for one particular taxpayer, between the grant of a tax advantage and the offsetting of that advantage by a fiscal levy ${ }^{103}$. In this regard is can be confirmed that the direct link doctrine would expel the anti-capitalisation rule from the scope of the justification based on fiscal coherence. Perhaps the Court of Justice has tried to limit the potentia-

${ }^{101}$ Commission/Belgium, cit., para. 45; Commission/France, cit., para. 27, and Cadbury Schweppes and Cadbury Schweppes Overseas, cit., para. 50.

${ }^{102}$ Judgment of 17 january 2008, Lammers \& Van Cleeff (Case C-105/07) ECLI:EU:C:2008:24.

${ }^{103}$ Judgment of 6 june 2000, Verkooijen (Case C-35/98) ECLI:EU:C:2000:294. 
lly high ripple effect of the fiscal coherence doctrine through the direct link doctrine, but in doing so is probably also closing doors to balanced judgments ${ }^{104}$.

143. In any case, in those cases in which the indebtedness is disproportionate, or has a sole objective of eroding the tax bases; is justified and is suitable to ensure the attainment of the objective in question, it's possible to understand that a thin capitalisation rule pursues a legitimate objective.

\section{B) The jurisprudential doctrine of justification}

144. It has been sufficiently expressed in the work that employment of the UE freedoms to achieve the implementation of a certain favourable legal regime cannot invoke to justify a general presumption of abusive practices or to serve as justification to measures that go against their effective practice ${ }^{105}$.

145. Being genuine UE freedom rights subjected to the economic agents that operate in the common market and are invoked before the States where they want to carry out an economic activity or investment, or before their States of residence ${ }^{106}$, it is settled case-law that the fact of the existence of an advantage resulting in a lower tax burden that is being submitted in a Member State of origin, does not solely justify that the State of origin claims to compensate this advantage with a less favourable tax treatment to the resident company within $\mathrm{it}^{107}$.

146. Similarly, the need to avoid the risk of tax evasion does not solely justify a discriminatory or restrictive treatment of the fundamental freedoms ${ }^{108}$ and especially the freedom of establishment, the Court of Justice has since declared that the circumstance in which the company has constituted itself in a Member State with the aim of benefitting from a more favourable legislation, is not solely sufficient to reach a conclusion that an abuse of this freedom exists ${ }^{109}$.

147. Thus, from the study on the doctrine of the Court of Justice it can be confirmed that only those anti-abuse rules which are designed to render ineffective the artificial transactions that do not contain real economic substance, and whose existence is aimed at obtaining a tax advantage with no other valid reason, can justify a discriminatory or restrictive treatment of fundamental freedoms.

\section{a) The jurisprudential analysis of national anti-abuse tax law}

148. As we have already mentioned, the proportionality implies that the suitability of the means used for the proposed purposes, the suitability of the employed instruments and their character, are necessary and limited in reaching the objective in question. In this way, the Court, applying the rule of reason will firstly analyse if the objective pursued by that anti-circumvention rule is legitimate and justified by overriding reasons of general interest ${ }^{110}$.

149. From among the causes that are accepted by the Court as justified from the adoption of restrictive or discriminatory measures by the Member States, and that we have already had the chance

\footnotetext{
${ }^{104}$ E. Sanz Gadea, "Medidas antielusión fiscal”, in Documentos de Trabajo del Instituto de Estudios Fiscales, no 18/09, 2009, p. 63.

${ }^{105}$ Commission/Bélgium, cit., X e Y, cit., Commission/France, cit., and Cadbury Schweppes and Cadbury Schweppes Overseas, cit.

${ }^{106}$ A. Martín JimÉnez, "Globalización y derecho tributario: el impacto del derecho Comunitario sobre las cláusulas antielusión/anti-abuso del derecho interno", cit., p. 6.

${ }^{107}$ Judgment of 3 october 2002, Danner (Case C-136/00) ECLI:EU:C:2002:558, para. 56.

${ }^{108}$ Judgment of 11 december 2003, Barbier (Case C-364/01) ECLI:EU:C:2003:665, para. 71.

${ }^{109}$ Centros, cit., para 27, and Inspire Art, cit., para. 96.

${ }^{110}$ Rewe-Zentral $A G$, cit., para. 14.
} 
to examine the fight against abusive practices the main interest is to observe their treatment by the jurisprudence of the Court and in relation with the freedom of establishment: a national measure that restricts the freedom of establishment may be justified where it specifically targets wholly artificial arrangements aimed at circumventing the application of the law of the Member State concerned. In assessing the behaviour of the person subject to taxation, they must take into particular consideration, the purpose for the freedom of establishment ${ }^{111}$ and this aim is to allow a national in a Member State to create a secondary establishment in another Member State in which it can practice its activities and thus favour the economic and social interpenetration within the $\mathrm{UE}^{112}$.

150. From this it deduces that in order for a restriction on the freedom of establishment to be justified for motives of fighting against abusive practices, the specific aim of this restriction must object to consistent behaviours in creating purely artificial arrangements, which do not reflect economic reality, with the aim to avoid the taxes normally owed on the benefits generated by activities carried out in national territory, such as it shows in both the ICI sentence and in Metallgesellschaft and others.

151. The Court of Justice has recognised on a number of occasions that the Member States may justifiably adopt measures that would be branded as discriminatory under different circumstances, in order to prevent abuse of law, as made clear in the Marks \& Spencer sentence, in which the Court of Justice declared that firstly, a restrictive national rule on the deduction of cross-border losses could be justified by the risk of tax evasion, and in particular the risk that, within a group of companies, the losses were transferred to the established companies in the Member States that applied higher tax rates and where the tax value of losses was higher ${ }^{113}$.

152. The main reason behind the recognition of this justification is that the taxpayers try to organise their (cross-border) fiscal positions more advantageously, but to the extent that such an organization conforms to reality: in other words, there is no question of a purely artificial arrangement directed to abuse or to avoid the national fiscal legislation. However, this justification does not comply if the rule applies to all types of situations and moreover, most of the anti-abuse provisions that exist to prevent the elusion through wholly artificial arrangements in defence of their legitimacy have been rejected by the Court such as, the allegations that expected to defend objectives of merely economic character, such as the loss of tax revenue, constantly invoked by the Member States and that do not constitute for the Court an overriding public interest ${ }^{114}$ under any concept.

153. In fact, the Commission states that there is a urgent need to find a fair balance between public interest in combatting abusive practices and the need to avoid an exaggerated restriction of the cross-border activity within the $\mathrm{EU}^{115}$ and, according to settled case-law, only a justification based on the fight against tax fraud is permissible when its intended purpose is to have wholly artificial arrangements designed to circumvent the tax law, which excludes all general presumption of fraud.

154. Therefore, a general presumption of evasion or of tax avoidance cannot be enough to justify a fiscal means that goes against the objectives of the Treaty ${ }^{116}$.

\footnotetext{
${ }^{111}$ Centros, cit., para. 25, and Xe Y, cit., para. 42.

${ }^{112}$ Reyners, cit., para. 21

${ }^{113}$ Marks \& Spencer, cit., paras. 49 y 50, Lankhorst Hohorst, cit., X e Y, cit., ICI, cit., Leur Bloem, cit., and Judgment of Halifax, cit.

${ }^{114}$ Verkooijen, cit., para. 48.

${ }^{115}$ Opinion of the European Economic and Social Committee on the Communication from the Commission to the Council, the European Parliament and the European Economic and Social Committee - The application of anti-abuse measures in the area of direct taxation - within the EU and in relation to third countries COM (2007) 785 final (2009/C 77/29), para 2.3.

${ }^{116}$ Commission/Belgium, cit., para. 45; Commission/France, cit., para. 27, and Cadbury Schweppes and Cadbury Schweppes Overseas, cit., para. 50.
} 
155. The next question that the Court must address in the development of the rule of reason is if the legislation in question, or the anti-abuse measure analysed is adequate to achieve the target objective. In Cadbury, the Court pleaded that by providing for the inclusion of the profits of a CFC subjects to very favourable tax regime in the tax base of the resident company, the legislation on CFC's makes it possible to thwart practices which have no purpose other than to escape the tax normally due on the profits generated by activities carried on in national territory.

156. As it has stated, such legislation is therefore suitable to achieve the objective for which it was adopted ${ }^{117}$. In the Test Claimants matter it questions if the legislation in question is appropriate to achieve this objective, concluding that it is both legitimate interests that are pursued in imposing that the cross-border groups qualify, abusively and artificially, as interest payment for loans which in reality are distributions, the requalification of the interest payments as distributions is obviously effective in counteracting such abuse ${ }^{118}$.

157. However, in $X$ and $Y$, the Court once examined the controversial rule, understanding that this disposition does not have a specific aim to deny the application of a tax advantage for purely artificial arrangements whose aim is to avoid the tributary regulations but that generally refers to, whichever situation in which, for whatever motive, the transfer at undervalue is in favour of a company incorporated under the laws of another Member State in which the transferor or a subsidiary of that company participates. To do this, it should be noted that the measure applied does not get to reach the objective that it supposedly follows, specifically, effective taxation in the host Member State of the transferor for capital gains on shares transferred, particularly if the transfer is made before the transferor definitely transferred their residence abroad.

158. Ultimately, as we can observe, it is absolutely essential for the Court that, together with the aim the anti-circumvention rule targets, the rule itself is adequate to achieve this aim ${ }^{119}$.

159. The final question that must be addressed with respect to the rule of reason is if whether the legislation in question is a facility provided in order to obtain this objective.

160. On this issue, depending on their design and implementation, a legislation directed at preventing the use of purely artificial arrangements may, at first, be a proportionate measure against abuse. To determine when a measure is proportional requires a trial of comparability in which it must examine if other less burdensome legislations can exist than that in question to achieve the proposed aim, analysing if the sacrifice of another interest in favour of another legislation could reduce.

161. An anti-abuse rule has as a legitimate aim, the fight against abusive practices and may contain a measure that is suitable for the obtainment of that aim, but all this is compatible with the UE Law to the extent that this provision is proportional to the following aim: as we said, the irrebuttable presumptions of abuse are rejected by generalists, or inadequate to achieve the intended purpose that is no other than to prevent the misuse of the UE freedoms and rights, without that objective, it can dislodge a restriction such that threatens its exercise.

162. To the extent to which the fundamental objective of a regulation is to prevent the use of elusive mechanisms, the proportionality test implies that it must guarantee that the rule at issue solely applies to avoiding purely artificial arrangements, such as how we have shown in the current work.

\footnotetext{
${ }^{117}$ Cadbury, cit., para. 59.

${ }^{118}$ Opinion of Mr. Advocate GeElhoed in Test Claimants in the Thin Cap Group Litigation, cit., para. 64.

119 Judgment of 11 november 2007, Elisa (Case C-451/05), ECLI:EU:C:2007:594, para. 81.
} 
163. For this purpose, the Advocate General GEELHOED ${ }^{120}$ confirms that «however, the formulation and application in practice of such a test must also satisfy the requirements of proportionality. In my view this means that: a) It must be possible for a taxpayer to show that, although the terms of its transaction were agreed with the independent parties, there were nonetheless genuine commercial reasons for the transaction other than obtaining a tax advantage; b) If such commercial reasons are put forward by the taxpayer, their validity should be assessed on a case-by-case basis to see if the transactions should be seen as wholly artificial arrangements designed purely to gain a tax advantage; c) The information the taxpayer must provide in order to rebut the presumption should not be disproportionate or mean that it is excessively difficult or impossible to do so; d) In cases where the payments are found to be abusive (disguised distributions) as already mentioned, only the excess part of the payments over what would have been agreed with independent parties should be recharacterized as a distribution and taxed in the subsidiary's state of residence accordingly; and; e) The result of such examination must be subject to judicial review».

164. In Ampliscientifica ${ }^{121}$ the Court, referring to the principle of proportionality considers that a national legislation which, lays down a time limit of between one and two years for taxpayers to be able to make VAT declarations and payments in accordance with simplified procedures is, in the light of the objective of combating tax evasion and bogus legal arrangements, consistent with the principle of proportionality.

165. The absence of a term could have had the effect of allowing the implementation of specific operations to justify the ad hoc creation of a legal structure, favouring abuse and fraud whose prevention is precisely one of the aims pursued by UE Law ${ }^{122}$.

166. As we have seen, to the extent that the purpose of a rule is to combat abusive practices, it must guarantee that it applies itself exclusively to the attainment of this purpose, that is none other than to avoid the existence of wholly artificial arrangements and that is thus suitable for this objective. Lastly, to demand to the Court that each element of the anti-abuse regulation is defined coherently with UE rights and freedoms, will equally demand that a proportionality test is carried out which requires a judgement of comparability that must examine if, to obtain the aim pursued, other less burdensome measures can exist than the one in question, and analysing if the sacrifice of an interest in favour of another could have been reduced.

\section{b) Proportionality test and the existence of wholly artificial arrangements}

167. As we have been able to analyse, the essential content of the freedom of establishment implies the possibility that a national citizen participates continuously and in a stable manner to the economic life of a Member State different to that that was originally theirs, therefore it seems logical to conclude that abuse will consist in the compliance with the formal requirements of the host without this they participate, fully and effectively, in the economy of the existing state, in exchange the desire to make a profit by artificially creating the conditions required for its obtainment ${ }^{123}$.

168. The Court has held that the discovery of the existence of a permanent establishment must base itself on objective and verifiable elements by third parties relating particularly to the level of physical existence of premises, staff and equipment.

\footnotetext{
${ }^{120}$ Opinion of Mr. Advocate GeELhoed in Test Claimants in the Thin Cap Group Litigation, cit., para. 67.

${ }^{121}$ Judgment of 22 may 2008, Ampliscientifica (Case C-162/07) ECLI:EU:C:2008:301.

122 Judgment of 15 june 2006, Heintz van Landewijck (Case C-494/04) ECLI:EU:C:2006:407, paras. 42-43, and Judgment of 13 december 2007, Batig (Case C-374/06) ECLI:EU:C:2007:788, para. 39.

${ }^{123} \mathrm{COM}$ (2007) 785 final, p. 3.
} 
169. If the verification of such elements leads to the finding that there is a fictitious establishment in which no effective economic activity in the territory of the host Member State is not exercised, should be considered that the establishment has the character of a wholly artificial arrangement ${ }^{124}$.

170. Similarly, we have been able to conclude that the implementation of cross-border operations, with the objective of benefitting from a more favourable legislation is fully covered by the Treaty, even if this is carried out for tax advantage purposes in terms of saving, such as a national citizen cannot be deprived of the possibility of invoking dispositions from the Treaty to capitalise from the tax advantages legally offered by the regulations in force in a different Member State to that in which it resides ${ }^{125}$. It is therefore clear that such actions contemplated as valid by law are limited only by the existence, in its exercise, of an additional element of abuse ${ }^{126}$.

171. In this regard, the Commission already pointed the need to explore the scope for establishing a non-exhaustive inventory of fact patterns that generally indicate the presence of an artificial arrangement - by way of example, incorporation of a secondary establishment which purports to provide goods or services from another jurisdiction without any real substance or physical operation therein, or more generally, types of arrangements which serve no business purpose (or which might be even contrary to general business interests, if not entered into for the purpose of avoiding tax $)^{127}$.

172. As we have also already analysed in some depth, the Court has been constant in their postulate that the existence of abuse must be casuistry, such that the irrebuttable presumptions of abuse are rejected by generalists, or unsuitable to achieve the intended purpose that is simply to prevent the abuse of UE freedoms and rights, to the extent that, the fundamental aim of a rule is the prevention of the use of elusive mechanisms, the criteria of proportionality implies that it must guarantee that the rule in question applies solely to avoiding wholly artificial arrangements.

173. However, and although the assertion of the Court of Justice, in the majority of their sentences, allows only those anti-abuse regulations whose aim is to stop conducting artificial transactions, which do not reflect economic reality and that have as their sole or main aim to obtain a tax advantage with no other valid motive, it seems loud and clear, that the problem arises in the definition of the term artificial, meaning the total lack of economic substance, but it is defined in such a way that it is considerably closer to the simulation.

174. Additionally, the Court demands that there is a close causal link between the suspicious transaction and the tax advantage, which implies that all anti-abuse regulations must focus a clear connection between the intended purpose of the taxpayer to achieve a certain beneficial tax treatment, and the definition of wholly artificial arrangements ${ }^{128}$.

175. Before this need to define the term artificial the Court has identified a series of factors that do not constitute by themselves and in isolation as a wholly artificial arrangement, for example, the mere fact that a subsidiary is established in another Member State does not imply in itself as tax evasion ${ }^{129}$, and the fact that the activities carried out for a secondary establishment in another Member State can be developed likewise by the taxpayer from the territory of their Member State of origin, does not necessarily mean that a wholly artificial arrangement exists ${ }^{130}$.

\footnotetext{
${ }^{124}$ Cadbury, cit., paras. 67- 68

${ }^{125}$ Barbier, cit., para. 71.

${ }^{126}$ G. Gonzalez García, "Una aproximación al contenido de los conceptos de discriminación y restricción en el Derecho de la Unión”, in Documentos de Trabajo del Instituto de Estudios Fiscales, nº 8, 2004, p. 42.

${ }^{127}$ COM (2007) 785 final.

${ }^{128}$ V. Ruiz Almendral, “¿Tiene futuro el test de los motivos económicos válidos en las normas antiabuso?”, cit., p. 36.

${ }^{129}$ ICI, cit., para. 26.

${ }^{130}$ Cadbury, cit., para. 69.
} 
176. It is completely legitimate for tax considerations to play a role in the decision on where to establish a subsidiary ${ }^{131}$ since the objective of minimising one's tax burden is a valid commercial consideration, as long as the arrangement entered into is not achieved through the artificial transfers of profits ${ }^{132}$, which brings us irretrievably to the analysis of the positive concept of purely artificial arrangements which the Court has considered essential in its construction of the doctrine of abuse.

177. According to the Factortame $I I^{133}$ judgement, the notion of establishment involves the actual pursuit of an economic activity through a fixed establishment for an indefinite period. They must simultaneously ${ }^{134}$ take the requirements of developing a real economic activity through a permanent establishment that has sufficient material resources, to be carried indefinitely and that obviously takes place in a different Member State of origin.

178. In general, the effective practice of an economic activity supposes to offer goods and services in the market ${ }^{135}$, which includes the production and commercialisation of products, the establishment of services and the exploitation of tangible or intangible assets to obtain returns whilst the demand of permanent establishment leads to examine the existence and availability of premises, staff and equipment necessary to perform the services ${ }^{136}$, although it is expressed in the simple existence of an office ${ }^{137}$. Thus, in order that it can be considered that a real and effective establishment exists, through the creation of subsidiaries or branches, whether it's primary or secondary, it is necessary that this is seen as capable to offer goods and services with a more or less autonomous management, although the ultimate control is carried out from a head office situated in another Member State. Further complications seem to have the requirement of the establishment remaining indefinitely to avoid being classified as abusive, as noted in the Leur-Bloem ${ }^{138}$ judgement.

179. In effect, the creation of structures for a limited time can be indicators of purely artificial operations, known as $u$-turns as well as those operations in which a transfer of residence is claimed temporarily, that allows other particular operations to have a considerable tax saving (and against those it operates, as anti-circumvention mechanism, the Exit Taxes).

180. However, the Court will confirm an operation destined to create a certain structure for a limited period and not sustainably, may obey valid economic motives ${ }^{139}$ which again supposes a need of a substance-overform analysis, to detect when we are actually facing a purely artificial arrangement.

181. In this respect, the so-called business purpose test doctrine is configured as a development of the finalist or teleological interpretation of the tax regulation and encompasses diverse doctrines that have a point in common, that is none other than denying the legal protection of those acts or businesses carried out without a real bargaining aim or abusing the rules that recognise these legal forms in the sense of using them to obtain a result (tax advantage) that is not the purpose for which the rule was created ${ }^{140}$.

182. Thus, in the Cadbury case, the General Advocate LEGER is going to elaborate a test based on three elements ${ }^{141}$ that must serve to differentiate when we are facing an artificial arrangement and

\footnotetext{
${ }^{131}$ Cadbury, cit., para. 37.

${ }_{132}$ Judgment of 26 october 1999, Eurowings (Case C-294/97) ECLI:EU:C:1999:524, para. 44.

${ }^{133}$ Factortame II, cit., para. 20.

${ }^{134}$ D. Weber, "Tax avoidance and the EC Treaty Freedoms: A study of limitations under European tax law to the prevention of tax avoidance", Kluwert Law International, La Haya, 2005, p. 31.

${ }^{135}$ Judgment of 16 june 1987, Commission/Italy (Case 118/85) ECLI:EU:C:1987:283, para. 7.

${ }^{136}$ Opinion of Mr. Advocate LegER in Cadbury, para. 112.

137 Judgment of 4 december 1986, Commission/Germany (Case 205/84) ECLI:EU:C:1986:463, para. 21.

${ }^{138}$ Leur-Bloem, cit., para. 35.

${ }^{139}$ Leur-Bloem, cit., apartado 42.

${ }^{140}$ V. Ruiz Almendral, “¿Tiene futuro el test de los motivos económicos válidos en las normas antiabuso? (sobre la planificación fiscal y las normas anti-abuso en el derecho de la Unión Europea)”, cit., p. 36.

${ }^{141}$ Opinion of Mr. Advocate Leger in Cadbury, paras. 112-114.
} 
when facing a true practice of the freedom of establishment: the first of the requirements deals with the reality of the implementation of the subsidiary in the welcoming State, and leads to examine if the necessary facilities, staff and equipment are available for the implementation of the services rendered by the parent company.

183. The second requirement refers to the effective character of the rendered services by a subsidiary, requiring examining of the competence of the staff with relation to the rendered services when making decisions in the implementation of these services. These amounts to assuming that if all decisions are adopted out of the subsidiary, this results in being only a mere instrument of execution, which would amount to an artificial arrangement.

184. The Court will not consider this second requirement, not only in this judgement but in those subsequent to it, such as, Eurofood IFSC, in confirming that in determining the centre of the main interests of a debtor company, the simple presumption laid down by the UE legislatation in favour of the registered office of that company can be rebutted only if factors which are both objective and ascertainable by third parties enable it to be established that an actual situation exists which is different from that which locating it at that registered office is deemed to reflect.

185. This could be so in particular in the case of a company not carrying out any business in the territory of the Member State in which its registered office is situated. By contrast, where a company carried out their business in the territory of the Member State where its registered office is situated, the mere fact that their economic choices are or can be controlled by a parent company in another Member State is not enough to rebut the presumption laid down by that Regulation ${ }^{142}$.

186. Finally, the third of the requirements relative to the value added by the activity of the subsidiary, is without a doubt more delicate in applying if the rendered services correspond effectively to the real activities carried out in the hosting State: this criteria allows to take into consideration the objective situation in which the rendered services by the subsidiary lack all economic interest with relation to the activity of the parent company, which would enable us to recognise the existence of a purely artificial arrangement in both the lack of benefit payment by the parents company and the counterpart, making it possible to consider an outright transfer of benefits from the parents company to the subsidiary.

187. This requirement may be applicable to those complex operations that have as their only purpose, to provide unity to isolated legal acts which together make sense in relation to the tax advantage that intends to strengthen, or in an intangible nature reveal many applicative problems in companies, to name an example; that have no productive nature but provide intra-group services of a financial nature ${ }^{143}$.

188. In most cases, the Court in their resolution, will not welcome all the requirements exposed by the Advocate General LEGER for the verification of the existence of an artificial arrangement, but that will restrict to value the reality of the implementation of the subsidiary in the hosting State determining it by the availability of premises, staff and equipment needed for the carrying out of rendered services to the parent company.

189. In this way, a restrictive concept of artificial arrangements ${ }^{144}$ is understood, limiting the application of the rules of Fiscal transparency, and leaving aside the assumptions in which, simply en-

\footnotetext{
${ }^{142}$ Eurofood IFSC, cit., paras. 34-35.

${ }^{143}$ P.M. Herrera Molina, "STJCE 12.9.2006 (Gran Sala), Cadbury Schweppes, As. C-196/04: Las cláusulas antiabuso de ámbito exclusivamente internacional pueden basarse en presunciones iuris tantum (a propósito de la subcapitalización)", in P.M. Herrera Molina (Dir.), Comentarios de jurisprudencia comunitaria del Tribunal de Justicia de las Comunidades Europeas 2006-2007, Instituto de Estudios Fiscales, Madrid, 2009, p. 5.

${ }^{144}$ Cadbury, cit., para. 67.
} 
dowed with a minimum economic and institutional introduction, the reality of the establishment is more suited to a substance manufactured for profit rather than a genuine exercise of freedoms and rights under the Treaty.

190. In RUIZ ALMENDRAL ${ }^{145}$ and SANZ GOMEZ ${ }^{146}$ opinions this interpretation leads to the conclusion that, for the Court, the concept of abuse without further representation, would amount to the Court focusing on those close behaviours to crude simulations ${ }^{147}$ as the essential nature of any abusive behaviour when applying the artificiality of the operations.

191. Despite what has been said the Court will require, accordingly with the jurisprudence established in the Emsland Stärke ${ }^{148}$ judgement, the combination of two elements for determining the existence of a purely artificial arrangement. These are firstly; a subjective element consisting of the intention to obtain a tax benefit and, secondly, that this results from the objective and verified elements by third parties, particularly at the level of physical existence of establishment where premises, staff and equipment are concerned. This will determine if, despite that they have formally respected the conditions foreseen by the EU Law, it has not reached the intended objective of the freedom of establishment ${ }^{149}$.

192. If from the verification of such elements it was gathered that the establishment constitutes a fictitious implementation that does not carry out any effective economic activity in the territory of the hosting Member State, it should consider that such creation has the characteristics of a purely artificial arrangement, which is it exactly what is at risk of happening particularly in the cases of a shell or letterbox subsidiary ${ }^{150}$ or in letterbox companies ${ }^{151}$.

193. In this sense, the abuse will assume the conjunction of these two intrinsically linked and relative criteria, on one hand, it is necessary to detach a number of objective factors that despite formal observance of the requirements of UE law, the intended purpose is not achieved for this rule: the objective criterion refers to the existence of a contradiction between the outcome achieved and the intended purpose of the UE provision or the freedom at stake. However, the contradiction of the outcome with the intended aims cannot itself characterise as an abusive practice, since through the obligations of UE Law the advantage obtained cannot be objectively justified by any other consideration than that to circumvent the rules in the national regulations.

194. For this, it is essential to take into account the purely artificial character of these operations and must appreciate, how we have already developed, through elements ascertainable by third parties of which the absence of an actual establishment is discarded that's intended for the effective realization of economic activities. Henceforth, the analysis must focus on what the intended outcomes for the UE legislations are, in case that, once delimited, proceeding to determine whether the prosecuted situation is integrated into these objectives. The objective element thus contains two requirements, which are on one hand an absolute estrangement between the purpose for which the circumvented rule was created and on the other, the carrying out of operations whose essential (and only) aim is to obtain an advantage that otherwise had not been possible to obtain.

${ }^{145}$ V. Ruiz Almendral, “¿Tiene futuro el test de los motivos económicos válidos en las normas antiabuso?”, cit., p. 36.

${ }^{146}$ R. SANz Gómez, "Las cláusulas anti-abuso específicas tributarias frente a las libertades de circulación de la Unión Europea", cit., p. 105.

${ }^{147}$ J.M. Calderón Carrero and A.J. Martín Jiménez, “Acerca de la necesidad de reconfigurar la política española en materia de cláusulas antiabuso y fiscalidad directa: las consecuencias derivadas de los casos Cadbury Schweppes y Test Claimants in the Thin Cap Group", in Jurisprudencia Tributaria, Aranzadi, n 2, 2007.

${ }^{148}$ Emsland Stärke, cit.

${ }^{149}$ X e Y, cit., paras. 41-42, Eurofood IFSC, cit., paras. 34-35 and Ampliscientifica, cit., para. 21.

${ }^{150}$ Eurofood IFSC, cit., paras. 34-35.

${ }^{151}$ Judgment of 30 september 2003, Inspire Art (Case C-167/01) ECLI:EU:C:2003:512, para. 101. 
195. However, the subjective element, consisting in the intention to obtain a tax advantage, will be more problematic: firstly, because it must complement itself by adding the requirement that such a benefit be obtained by artificially creating the conditions needed for its obtainment ${ }^{152}$.

196. Based on the premise that a UE national cannot be deprived of the possibility of invoking the Treaty provisions because of profiting from tax advantages which are legally provided by the rules in force in a Member State other than that in which it resides ${ }^{153}$, the Court warns that if the subjective element is literally in the intention to obtain a tax advantage, it should be treated with caution. In this respect, Advocate General POIAREA MADURO ${ }^{154}$ believes that, to determine the existence of a subjective element as mentioned in the Emsland-Stärke judgement, does not affect the interpretative character of the concept of abuse in EU Law since the Court of Justice linked this subjective element with the conclusion that the situation that prompts the application of a certain UE law was merely artificial.

197. This conclusion of artificiality, in his opinion, must not be based in appreciation of the subjective intentions which invoke the UE law but that must explain the base of a series of verified objective circumstances in each particular case.

198. The intention is not critical to value the abuse, but the activity itself is objectively considered since the parties' intentions to abusively obtain a benefit are simply deductible of the artificial character of the situation that has to be assessed in the light of a set of objective circumstances ${ }^{155}$.

199. The subjective element can only verify the purpose of the activities carried out for the obtainment of the elusive aim to an extent. Thus, the Court sustains that in order to find a permanent establishment it must be based on objective elements and ascertainable by third parties and concerning the elements of judgement that have been studied in this piece of work, and if not verified, it should be considered that this creation has characteristics of a purely artificial arrangement. That said, in the Emsland-Stärke judgement it will be established that it corresponds to the national court accrediting the existence of these elements, whose evidence must conform with the national regulations and as long as it does not damage the efficiency of EU Law ${ }^{156}$.

200. Ultimately, to the extent that the fundamental objective of an anti-abuse rule is the used as a prevention of the use of elusive mechanisms, the criterion of proportionality implies that the controversial rule must be applied solely to avoid purely artificial arrangements, and to constitute as the final section of this work, to define what is understood when the Court prosecutes those suspected of abuse.

201. From the jurisprudence of The Court of Justice it deduces that the anti-abuse rules cannot be formulated generally but must have as a clear and sole aim, to prevent explicitly circumvention, in other words, it must hope to exclude the fiscal advantage through abusive practices consisting of the creation of purely artificial arrangements.

202. As we saw, the Court established a triple analysis test on the anti-circumvention rule in order to verify its compatibility with the UE legislation in terms of the rule of reason and, in this respect, try to verify if the rule is justified on general-interest grounds, that the restriction be apt to ensure the

${ }^{152}$ Emsland Stärke, cit., paras. 52-53, Centros, cit., para. 24; Halifax, cit., paras. 74-75 and Cadbury Schweppes and Cadbury Schweppes Overseas, cit., paras. 64.

${ }^{153}$ Barbier, cit., para. 71.

${ }^{154}$ Opinion delivered on 7 april 2005 in Halifax.

${ }^{155}$ D. Anderson, “¿What is abuse of Rights?”, in Alba Conference, Cambridge, 29 july 2006: later cases have played down the subjective nature of the test, suggesting that intention should be inferred from objective circumstances.

${ }^{156}$ Deutsche Milchkontor and others, cit., paras. 17-25 and 35-39; Johnston, cit., paras. 17-21; FMC and others, cit., paras. 49-51 and Arco Chemie Nederland and others, cit., para. 41. 
attainment of the objective in question and that it does not go beyond what is necessary to attain that objective $^{157}$.

203. Thus, from the jurisprudential analysis of the EU test of proportionality it can be drawn that it is subject to the concurrence of a series of conditions that are: firstly, as we could conclude from the analysis on the Lankhorst Hohorst judgement carried out in this work, regarding the purpose of the disputed loan taken out by related entities, the reality was that this constituted a rescue attempt of the subsidiary, through full reduction of spending and the attainment of an important save on bank interests, although the conditions of this operation differ from those that were practiced within independent parties.

204. This type of situation in which an operation is not held between linked parties, and in conditions that were practiced between independent parties, can be considered as a purely artificial arrangement, but in any case, the demand of proportionality when applying the anti-abuse measure foreseen for such situations requires that it demonstrates that valid motives exist which can justify such operation, which could be understood by the Court as a concept of objective reasonableness ${ }^{158}$.

205. Secondly, as we have already noticed, it is the distribution of the burden of proof as it responds to the national legislation crediting the existence of indicative elements of the existence of a purely artificial arrangement lacking in actual economic motives, so the taxpayer must be entitled to oppose the application of anti-abuse rules, providing relative elements to possible valid reasons for which the transactions took place but without being subject to excessive administrative restrictions.

206. Thirdly, the anti-abuse regulation must only affect the party in operation that does not fit firstly with the principal of full competition, in other words, when a State demonstrates the existence of an abuse, the measure that it adopts as a reaction mechanism must also be proportional to the very purpose of the anti-abuse clause applied, so it should limit such reaction to reverse the consequences of the elusive operation, as the Court reveals in the Test Claimants judgement, when confirming that, in order that a measure is compatible with the principle of proportionality its necessary that in concluding the existence of a purely artificial arrangement lacking in providing any in real commercial reasons for said transaction in question, the re-characterisation of the interest paid as a distribution profit is limited to the proportion of the interests which exceeds what would have been agreed had the relationship between the parties been one at arm's length ${ }^{159}$, without any penalty arising ${ }^{160}$.

207. In short, the proportionality presupposes two interests that are relevant to the legal system and who are in conflict, with the aim of giving effect to this principle one of the interests in a manner least affecting the other, always referred to in terms of a specific case; in this case, not only the application of anti-abuse measure must be appropriate for securing the attainment of the objective but it also cannot go beyond what is necessary to achieve it.

208. Elements such as the burden of proof, the establishment of reasonable presumptive criteria, the permeability of the norm admitting exceptions to its application, or implementation of the own criterion of necessity involving a balance of proportionality between the stakes must be absolutely respected by the State seeking to enforce a confrontation with anti-circumvention measures in EU law and especially with the free exercise of fundamental freedoms.

${ }^{157}$ Gebhard, cit., Futura Participations and Singer, cit., de Lasteyrie du Saillant, cit., and Marks \& Spencer, cit.

158 J.M. Calderón Carrero, "STJCE 13.3.2.007, C-524/04, Case Test Claimants in the Thin Cap Group: las Condiciones de compatibilidad comunitaria de las cláusulas de subcapitalización (y de precios de transferencia)", in Comentarios de Jurisprudencia Comunitaria, Instituto de Estudios Fiscales, Madrid, 2007, p. 12.

${ }^{159}$ Test Claimants in the Thin Cap Group, cit., para. 83.

${ }^{160}$ Halifax, cit., para. 93. 


\section{A concept of an abuse in UE law in tax matters}

209. Before proposing a concept of an abuse in UE Law it may be appropriate to carry out some reflections on philosophical considerations that nourish the legal UE.

210. There are institutes specialising in the abuse of law and its understanding. Since their studies delve into the philosophical framework that nourishes positive Law, they cannot reach full understanding without carrying out a deep investigation on supra legal roots.

211. RODRÍGUEZ ARIAS examined this to perfection when he confirmed the legislator must pay attention due to the mutations in social matters when trying to avoid, where possible, maladjustments between the field of social and legal reality (...) so the theory of abuse of law arises to fill new needs in society ${ }^{161}$.

212. Every time it must be decided whether fault, negligence or recklessness has existed, or, where appropriate, when it is necessary to resort to standards of behaviour (such as diligent conduct a good man) in such a decision the idea of what is seen as reasonable, or not, is used. We have to admit without a doubt, that all the regulations and laws are orientated towards the achievement of a certain purpose, in such a way that whoever holds that right, or intends to enforce compliance with a standard, has discretion as to how to exercise it. However, such discretion must have certain limits, because if not, the subjective practice of law would involve the opposition of another opposing practice of law.

213. It is obvious that when making decisions on certain facts at legal level, it can lead us to a conclusion: that many outcomes exist. This paradox, that is not so easy if any speculative content is isolated, reveals the absolute truth; that when facing certain factual situations, the ambiguity of the wording of the required standard allows us to reach different and valid results. Meanwhile, whilst making decisions, this freedom of initial interpretation, as we have already said, leads us to the idea of what is and what is not reasonable. In this regard, reasonableness is a notion that is found increasingly more prominent at legal level, as a result of the idea of the complex reality that does not allow limits to be put in place.

214. Economic globalization and the breakdown of borders within the UE are two clear examples of the difficulty in finding a sealed reality. The continuous international legal flow makes it increasingly difficult to find a finished concept in Law, and in this respect the undefined legal concepts between those that find the reasonableness are legal instruments that possess a broad interpretive margin of discretion that allow to determine the correct solution in a particular case.

215. We will reasonably understand the term justified, non-arbitrary to then expand the term to the ordinary, the normal and the expected so that everything that is not within those conceptual boundaries is unreasonable and, therefore, not lawful. This is precisely where the notion abuse of law gets its full justification: the legality of the reasonable exercise of its own right, or fair compliance with a legal obligation, must be discovered when considering the aims that the Law had when recognising these laws and obligations, which manifestly exceed the usual limits of the practice of a right (legal standards of good faith, morality, and decency), which can be considered abusive and therefore unreasonable.

216. However, there hasn't always been an unanimity in the rational concept of law: authors such as DWORKIN ${ }^{162}$ who argues that the individuality of law, such as the monistic concept of law, completely faces the concept of general interest, understanding the legal principals as a simple justification of individual rights facing the rest of the claims, in such a way that they intended to avoid the risk of being subordinated to conflicting collective interests.

${ }^{161}$ L. Rodríguez ArIas, “El abuso del Derecho”, Ediciones Jurídicas Europa América, Buenos Aires, 1971.

${ }^{162}$ R. Dworkin, “Taking rights seriously”, 5ª ed. Peral Duckworth \& Co. Ltd., London, 1987. 
217. GLENDON amongst others believes that it is difficult to be able to accept the postulate in both confirming that it is impossible to admit if someone has the right to something, it is wrong for the State to deny them it, although doing so would favour the public interest ${ }^{163}$.

218. Based on this confrontation of ideas, it has split a referenced logic to absolute and irrevocable subjective rights, in order to get a more recent idea that defines the theory of abuse as an antisocial (abusive) practice of a subjective right. Thus, the figure of abuse of Law tends to condition the practice of law to notions that can reach to frustrate them, in the sense that a freedom of aims that would satisfy the practice of a law would go against the social interest for which the law was created ${ }^{164}$, with its functions, objectives or purposes created for only legitimately or reasonable exercise.

219. We can understand that the system decrees its regulations for its fulfilment, not in order to serve as a hedging instrument for different purposes than those that were given at its creation. In other words, to abuse the law does not consist of violating the rules per se, but that are in apparent conformity with it, in a juridical legitimacy of fulfilment that encloses an act that would have the obligation to not carry it out under the applied regulation.

220. The abuse proposes that, through the use of a recognised subjective right and protected by a regulation, it provokes damage to foreign (individual or collective, private or general) interest that is not protected by a specific legal prerogative and that is configured as something we can define as irrational or as ethically reprehensible. But how should the abuse of rights be treated? Applying moral, or ethics, in the configuration of whether the conduct being prosecuted is abusive, means the behaviour would be interpreted contextually, according to the morals and ethics of that who judges it. To define what goes against the justified, the non-arbitrary or the ordinary, normal and the expected by turning to the right, morality or the requirements of good faith (nihil est sine ratione cur potius sit, sit non quam) to define what is reasonable and what is not is a debate that, even today, to my mind remains open.

221. Consequently, to elaborate a concept of abuse of Law in the EU legislation and more concretely in the practice of the freedom of establishment that the Treaty embeds as one of the most fundamental freedoms, obliges us to carry out a series of conclusions that will be truly basic premises: on one hand, the undeniable right exists that helps citizens of the European Union to choose between those legal and tax regimes that would be more beneficial for their economic and personal interests, not invoking such election to raise a general presumption of abusive practices and serve the justification of measures that go against the practice of a fundamental freedom guaranteed by the Treaty.

222. Carrying out cross-border operations with the purpose of benefitting from a more favourable legislation is clearly covered by the Treaty, including if this operation is carried out for tax purposes, as a national citizen cannot be deprived of the possibility of invoking provisions of the Treaty to take advantage of the fiscal benefits legally offered by the rules in force in a Member State different from that in which is resides ${ }^{165}$.

223. As defined in Van Binsbergen, it is the fact of prevailing the UE Law in an abusive or fraudulent way that will be understood as an unreasonable practice, in other words, if it is practiced with the aim of obtaining illegitimate benefits that manifestly are not relative with the intended purpose of the rule. In this regard, the UE freedoms constitute an essential point of reference when determining the spirit and purpose of the anti-abuse rules established by the Member States, and so, its fundamental purpose is the construction of the Internal Market. This comes to reflect the main context in which the

\footnotetext{
163 A.M. Glendon, "Rights Talk: The impoverishment of political Discourse”, New York, 1991, p. 40.

${ }^{164}$ G. Palombella, "El abuso del derecho, del poder y del rule of law", in DOXA, Cuadernos de Filosofia del Derecho, no 29, 2006, p. 37.

165 Barbier, cit., para. 71.
} 
Court of Justice has analysed the concept of abuse, and that is none other than to abusively invoke the provisions of EU Law with the aim of obtaining advantages in a way that goes against the aims and objectives of these provisions.

224. As we have already analysed, the abusive practice requires the concurrence of an objective element composed of an absolute distance from the purpose for which the eluded rule was created and for the carrying out of operations whose essential (and only) aim is the obtainment of an advantage that in another way has not been possible to obtain. In conjunction, the demand for a subjective element will understand the willingness to obtain a fiscal advantage, to find an artificial fiscal evasion plan that will result as more problematic to delimit because, as the Court has made clear in its declarations. It will be the local court order who should set the actual content and significance of the transactions.

225. The requirement of this subjective element is not peaceful even within the Court itself, whilst in Emsland-Starke it puts the same standards for objective and evidentiary items, however in $\mathrm{Ha}$ lifax it will exclude it, inclining itself for the option that the legal system must take into consideration the purely artificial character of the operations to determine the existence of an abusive behaviour without the intentional element having greater involvement, just like in the legal, economic and/or personal natures of the links between the operators involved in the plan of reducing the tax burden.

226. Consequently, it is essential to take into consideration the purely artificial character of the operations that must be seen through elements verified by third parties on which the absence of an actual establishment intended for the effective deployment of economic activities is apparent, particularly where the actual presence of premises, staff and equipment is concerned.

227. If the verification of these elements deduces that a fictitious deployment exists in which no effective economic activity is carried out in the territory of the hosting Member State, it should be considered that this creation has the characteristics of a purely artificial arrangement and that it is not acceptable under the intended purpose of the UE legal system.

228. As we have seen, the change of scheme in the tax sphere has certain complex elements: it is obvious that it is difficult to accept that the tax burden reduction constitutes as an illicit advantage manifestly unrelated to the purpose of the UE legislation, and in this sense, the Court has manifested, as a reason to justify the application of anti-abuse measures, when rejecting purely economic causes in terms of tax collection.

229. The practice of the fundamental freedoms allows its use to make the most of the differences of tax treatment derived from the tax competition existing between the Member States; consequently, such use cannot be punished, under any concept, by national regulations. Only when their own objectives of the freedoms or the rules of secondary legislation have been breached abusively, is when such behaviour deserves response from the national regulations according with the UE regulations.

230. In conclusion, the abuse of Law supposes the act of overflow in a way that obtains a purpose remote from the one that is understood correctly, which requires interpretive work from the fundamental freedoms involved and as we have abundantly exposed, combining the teleological elements with the explained objectives. As a colophon to this work, and taking into account the jurisprudence of the European Court of Justice already analysed, we understand that a concept of abuse of law in the practice of the freedom of establishment could be defined as the practice consisting in the creation of purely artificial arrangements, lacking any real economic content, that is destined solely to circumvent the tax regulation, that in normal circumstances would have been a mandatory, with the sole aim of obtaining an illicit tax advantage. 